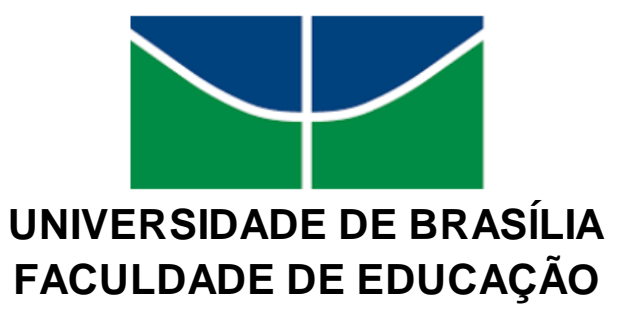

KESLANY CRISTINA VIANA DOS SANTOS

Relevância e potencialidades da utilização de materiais de Divulgação Científica para o processo de ensino e aprendizagem de ciências nos anos iniciais do Ensino Fundamental 


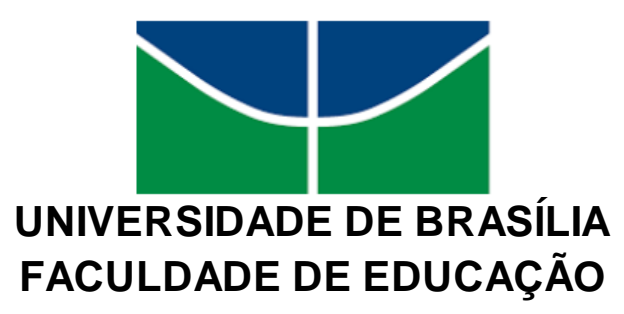

KESLANY CRISTINA VIANA DOS SANTOS

Relevância e potencialidades da utilização de materiais de Divulgação Científica para o processo de ensino e aprendizagem de ciências nos anos iniciais do Ensino Fundamental

Trabalho Final de Curso apresentado à Banca Examinadora da Faculdade de Educação da Universidade de Brasília, como requisito parcial e insubstituível para a obtenção do título de Pedagoga pela Universidade de Brasilia.

Orientador:

Prof. Dr. Hélio José Santos Maia

\section{Brasília-DF}


Ficha catalográfica elaborada automaticamente, com os dados fornecidos pelo(a) autor(a)

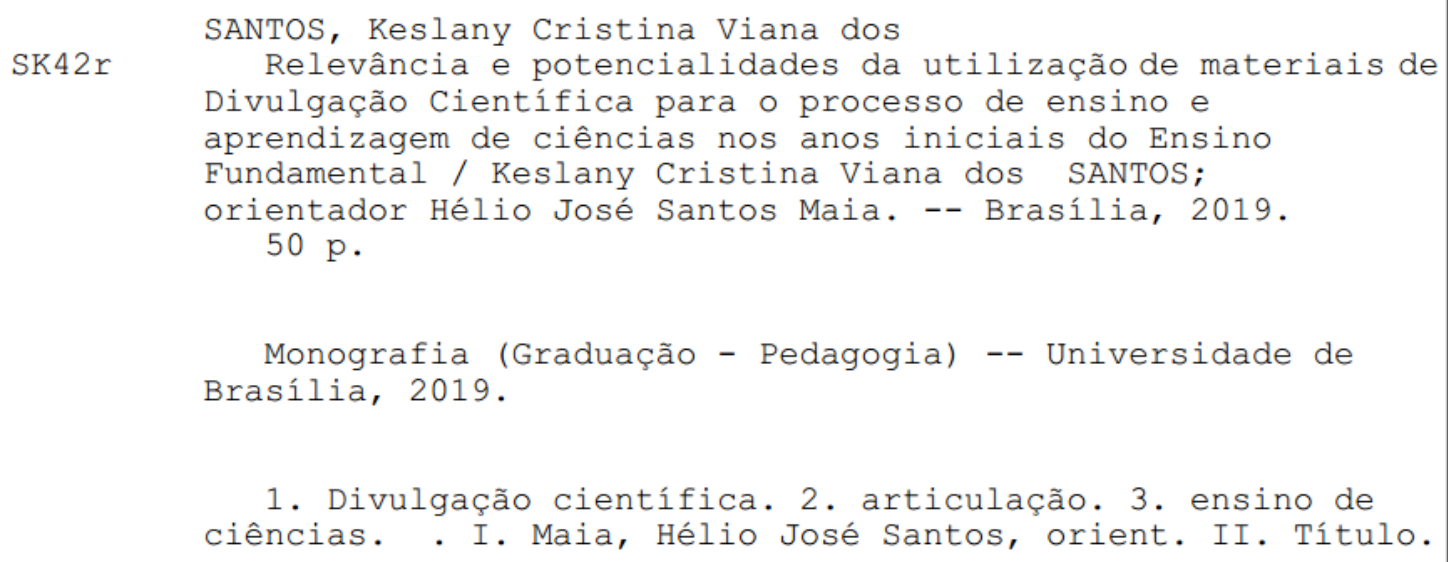

1. Divulgação científica. 2. articulação. 3. ensino de ciências. . I. Maia, Hélio José Santos, orient. II. Título. 
Relevância e potencialidades da utilização de materiais de Divulgação Científica para o processo de ensino e aprendizagem de ciências nos anos iniciais do Ensino Fundamental

\begin{abstract}
Monografia apresentada à banca examinadora da Faculdade de Educação da Universidade de Brasilia, como requisito parcial e insubstituível para obtenção do título de Graduação do Curso de Pedagogia da Universidade de Brasilia.
\end{abstract}

\title{
Aprovado em
}

Prof. Dr. Hélio José Santos Maia - (FE/MTC/UnB) Orientador

Profa. Dra. Eloisa Assunção de Melo (FE/MTC/UnB)

Examinadora

Profa. Dra. Rita Silvana Santana dos Santos (FE/MTC/UnB)

Examinadora

Profa. Msc. Verônica da Conceição Silva (SEEDF/PPGEMP/FE/UnB)

Suplente 


\section{Dedicatória}

Dedico esse trabalho de conclusão de curso a minha querida familia, que sempre esteve ao meu lado, me apoiando e me incentivando a investir e me dedicar cada vez mais aos estudos para alcançar meus objetivos, estando sempre torcendo pela minha vitória e ficando felizes com as minhas conquistas e sucesso. 


\section{AGRADECIMENTOS}

Primeiramente agradeço a Deus, por todo o seu amor e cuidado comigo. Por estar sempre presente em minha vida, me encorajando e dando forças para enfrentar qualquer desafio. Agradeço imensamente por me dar sabedoria para usufruir de todas as oportunidades que são colocadas no meu caminho. Obrigada Deus por todas as portas e oportunidades que o Senhor abre para que eu possa realizar meus sonhos e conquistar meus objetivos.

Agradeço a minha família, ao meu pai Sebastião, minha mãe Kelly e as minhas irmãs Ketlén e Ketlyslany que estão sempre ao meu lado almejando o meu sucesso e ficando felizes e gratos a Deus pelas minhas conquistas. Amo muito vocês. Em especial, agradeço ao meu pai, por ser o meu maior exemplo de honestidade, humildade e caráter. Admiro muito o homem forte e determinado que o senhor é, obrigada por todos os ensinamentos, pois são eles que me ensinam a ser uma pessoa melhor a cada dia. Palavras não são suficientes para expressar toda a minha gratidão. Eu te amo sem medidas.

Não poderia deixar de agradecer as minhas madrinhas Alexandra e Mara, pois sempre estiveram comprometidas em me ajudar com os estudos, me incentivando e apoiando nessa caminhada. Vocês são muito especiais. Também agradeço ao meu primo Enielson, que sempre se mostrou disposto a me auxiliar e dar suporte para estudar, se disponibilizando a investir nessa trajetória de estudos em tudo que se mostrava necessário.

Agradeço também a minha amiga Fernanda, você foi um grande presente que a UnB trouxe pra mim. Obrigada por ser a melhor companhia, por estar ao meu lado em todos os momentos, a sua amizade fez a rotina de estudos ser mais leve e feliz. Você não é só uma amiga, mas uma irmã. Agradeço você por todo amor e carinho.

Quero agradecer também a professora Graciella Watanabe, por toda a sua contribuição em minha formação acadêmica, por sua amizade e exemplo como profissional. Ao professor, Hélio José Santos Maia, tenho muito a agradecer por ter orientado e acolhido o meu trabalho. Obrigada pelos ensinamentos, instruções e qualificações ao longo desses semestres. Você é um exemplo de como ser um ótimo profissional.

Agradeço a Universidade de Brasília, aos professores e aos colegas que fiz por aqui, por me proporcionarem um imenso crescimento, tanto profissional como pessoal, foi um privilégio todas as experiências.

A vocês toda minha gratidão. 
"Não há saber mais ou saber menos: há saberes diferentes."

Paulo Freire. 


\section{RESUMO}

Esse trabalho parte de uma linha de pesquisa que busca apresentar reflexões e ações práticas para que articulação entre divulgação científica e o ensino de ciências nos anos iniciais possa ser entendido como um instrumento educacional de apoio, que favoreça o processo de ensino-aprendizagem, possibilitando que as atividades escolares tornem-se mais abrangentes e dinâmicas. Nesse sentido, a pesquisa se enquadra dentro das perspectivas teórico-metodológicas da pesquisa-ação. São apresentados em seu conteúdo, alguns materiais com finalidades educativas que foram produzidos com o intuito de serem inseridos nas aulas de ciências, objetivando mostrar como pode ser feita a articulação entre divulgação científica e o ensino de ciências, de modo a exemplificar como estes materiais possuem potencialidades para tornarem-se ferramentas educativas de apoio ao livro didático, trazendo para além da atualização de conteúdos, uma nova forma de abordagem com enfoque na temática da Divulgação Científica (DC). Optei por trabalhar com o canal de vídeo "De Onde Vem", pela disponibilidade e facilidade de acesso aos vídeos e também porque esse canal apresenta em seu conteúdo vídeos de curta duração, feito através de animações com enfoque nos conhecimentos científicos, apresentando uma linguagem acessível para o público infantil. No primeiro momento da pesquisa, explorei dois vídeos desse canal, e dessa maneira elaborei dois roteiros de aulas, um para cada vídeo, mostrando uma possibilidade de abordar o tema em sala de aula. $\mathrm{O}$ modelo de roteiro de aula foi pensado de maneira a contemplar um melhor aproveitamento do tempo da aula, de modo a favorecer a socialização dos conhecimentos a serem trabalhados entre o professor e os alunos. A partir da elaboração dos materiais, tornou-se essencial a produção de uma ficha de análise crítica para avaliar os roteiros de aulas que foram produzidos. Posteriormente essa ficha de análise crítica foi aplicada a quatro professores da educação infantil, objetivando conhecer os aspectos que os mesmos consideraram positivos e/ou negativos em relação a este material educacional de apoio, que busca, sobretudo, favorecer o processo de ensino-aprendizagem, de modo a tornar as atividades escolares mais abrangentes e dinâmicas, proporcionando reflexões e ações práticas alinhadas à temática da divulgação científica no contexto de sala de aula. A partir das respostas dadas pelos professores, foi possível certificar-se de que esses materiais proporcionam trocas de experiências e estratégias de socialização ao serem trabalhados em sala de aula, pois durante as discussões, realização de atividades e interação dos estudantes nas aulas, eles podem além de expressar suas ideias, compartilhá-las. Dessa maneira, foi possível concluir com essa pesquisa, que aliar a temática da divulgação científica com os conteúdos socializados nas aulas de ciências nos anos iniciais de escolarização, constitui-se como uma ferramenta didático-metodológica importante para promover aulas mais dinâmicas e interativas, potencializando uma maior participação e comunicação dos alunos no seu processo de ensinoaprendizagem.

Palavras-chave: Divulgação científica; articulação; ensino de ciências. 


\section{LISTA DE QUADROS E FIGURAS}

Quadro 1 Ficha de analise crítica......................................................... $\quad 39$

Figura 1 Print screen do site Ciência Hoje das Crianças............................ 28

Figura 2 Print screen do site Galileu......................................... 29

Figura 3 Print screen do site Mundo Estranho ......................................... 29

Figura 4 Print screen do Blogs de Ciências............................................ 30

Figura 5 Print screen do blog Humor com Ciência.................................... 30

Figura 6 Print screen do canal do Youtube "De Onde Vem?"..................... 31

Figura 7 Print screen do canal do Youtube "Ciência todo Dia"................... 31

\section{LISTA DE ABREVIATURAS E SIGLAS}

DC Divulgação Científica

CEMI Centro de Ensino Médio Integrado a Educação Profissional

PAS Programa de Avaliação Seriada 


\section{SUMÁRIO}

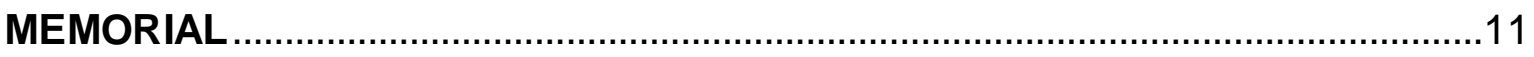

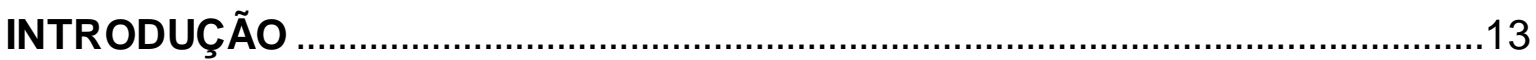

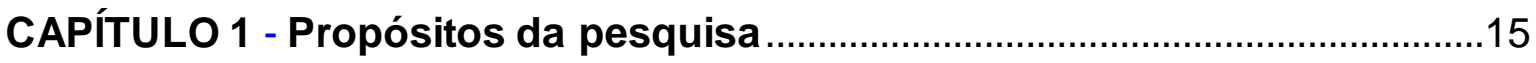

CAPÍTULO 2 - Uma fundamentação teórica ...................................................21

CAPÍTULO 3 - Dados da pesquisa, sua análise e resultados ...........................27

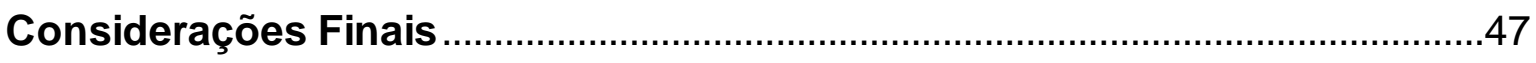

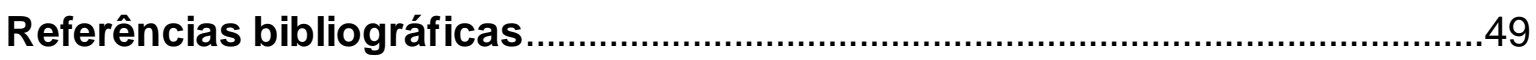




\section{MEMORIAL}

Eu sou Keslany Cristina Viana dos Santos, nasci em 07 de Novembro de 1996, em Brasilia - DF. Minha infância foi muito feliz com a participação dos meus pais e das minhas irmãs em minha formação. Estudei a pré-escola em uma escolinha pública do Estado de Goiás. Em 2005, quando mudei para a Ponte Alta no Gama-DF, comecei a estudar o Ensino Fundamental no Centro de Ensino Fundamental Casa Grande, uma pequena escola localizada em uma zona rural, onde os alunos são levados de ônibus escolar para as aulas. Achava isso muito divertido, ter que ir para a escola de ônibus. Cursei todo o Ensino Fundamental nessa mesma escola, e as recordações que tenho dessa fase de escolarização são alguns boletins e histórico escolar.

Em 2012, tive que mudar de escola, pois a antiga escola não ofertava 0 Ensino Médio. Assim, fiz a prova para estudar em uma escola integral localizada no Gama. Passei na prova, então fiz a minha matrícula no Centro de Ensino Médio Integrado a Educação Profissional - CEMI, onde estudei o primeiro ano do Ensino Médio. Nessa escola tive experiências muito significativas para minha formação escolar, era uma novidade estudar em período integral. Contudo, não me identifiquei muito com a proposta de ensino da escola, pois ela ofertava o ensino médio integrado com cursos de informática, não me identifiquei com as disciplinas técnicas ofertadas, e por esse motivo mudei de escola.

Em 2013, comecei a estudar no Centro de Ensino Médio 2 do Gama, e nessa escola concluí o Ensino Médio. Gostei muito dessa escola, tive experiências muito importantes, conheci ótimos professores que se dedicavam muito para cumprir com êxito o seu papel de auxiliar na formação de cidadãos críticos e reflexivos para lidar com as realidades do dia a dia. Assim, no final do terceiro ano do Ensino Médio, comecei a me perguntar sobre qual faculdade gostaria de iniciar após a conclusão do Ensino médio, estava em dúvida entre Biologia e Pedagogia. No final do ano, quando me inscrevi no Programa de Avaliação Seriada (PAS), escolhi o curso de Pedagogia, e fique muito feliz quando descobri que passei. 
Em 2015, iniciei o curso de Pedagogia na Universidade de Brasilia (UnB). Com todas as experiências e aprendizagens que tive durante o processo de formação acadêmica, me certifiquei de que fiz a escolha certa, pois me identifiquei muito com o curso e com a profissão de pedagogo. No decorrer da formação no curso, conheci a professora Graciella Watanabe e juntamente com ela e mais três colegas de curso, iniciamos um Projeto de Iniciação Científica na área de Divulgação Científica nos anos iniciais de escolarização. Foi uma experiência muito gratificante, pois acrescentou muito na minha formação ter que desenvolver e apresentar um projeto com ênfase na pesquisa acadêmica. Após isso, conheci o professor Hélio que me auxiliou nas disciplinas de Projeto 4 , de estágio supervisionado, e que posteriormente se tornou o meu orientador no Projeto 5 , de modo que ele acolheu o meu trabalho de pesquisa e me ajudou a dar continuidade a ele, com muitas contribuições, apresentando como resultado o presente trabalho de conclusão de curso. 


\section{INTRODUÇÃO}

O tema abordado nesta pesquisa refere-se à relevância e potencialidades da utilização de materiais de Divulgação Científica (DC) para o processo de ensino e aprendizagem de ciências nos anos iniciais do Ensino Fundamental, compreendidos por este trabalho, como sendo as séries correspondentes ao $1^{\circ}$, $2^{\circ}, 3^{\circ}, 4^{\circ}$ e $5^{\circ}$ ano, de modo a promover possibilidades no uso da divulgação científica. Esse trabalho parte de uma linha de pesquisa que busca reflexões e ações práticas para que articulação entre divulgação científica e o ensino de ciências nos anos iniciais e possa ser um instrumento educacional de apoio aos recursos mais corriqueiramente utilizados pelos professores, tal como o livro didático, buscando favorecer o processo de ensino-aprendizagem, possibilitando que as atividades escolares tornem-se mais abrangentes e dinâmicas no decurso das aulas. A partir de uma análise de trabalhos feitos e publicados sobre a articulação de materiais de DC e o ensino de ciências, no conteúdo desse trabalho, serão exibidos dois roteiros de aulas que foram elaborados seguindo alguns critérios destacados como relevantes por diferentes autores, para fomentar novas perspectivas de aprendizagem referentes a essa articulação. Posteriormente os dois roteiros foram entregues a quatro professores da rede pública de ensino, para que estes pudessem analisar se os mesmos possuem potencialidades para serem inseridos e trabalhados em sala de aula. Dessa forma, a elaboração dos roteiros de aulas, pautou-se no intuito de mostrar como a combinação de fontes alternativas de DC pode ser atrelada ao livro didático no âmbito das aulas de ciências, de modo a buscar favorecer o processo de ensino e aprendizagem dos alunos, a partir da mediação desses recursos pelos professores. Em seguida, esta pesquisa apresenta uma ficha de análise crítica que foi produzida com o objetivo de ser aplicada aos mesmos professores que receberam os roteiros de aulas. Essa ficha é composta por perguntas que almejam identificar se os professores consideraram os roteiros de aulas, materiais significativos para promover melhorias nas abordagens de conhecimentos científicos nas aulas de ciências e com potencialidades para promover uma interlocução com outras áreas de conhecimento. Assim, mediante as respostas 
obtidas, foi possível fazer uma análise que permitiu inferir que alinhar a temática da divulgação científica com os conteúdos socializados nas aulas de ciências nos anos iniciais de escolarização constitui-se como uma ferramenta didáticometodológica importante para promover aulas mais dinâmicas e interativas, potencializando uma maior participação e comunicação dos alunos no seu processo de aprendizagem. Possibilita também ao professor a utilização de materiais de apoio ao livro didático, de modo a fomentar um melhor aproveitamento da aula a partir de práticas pedagógicas e ambientes de aprendizagens que possibilitam explorações ativas e uma maior interação social. 


\section{CAPÍTULO 1 Propósitos da pesquisa}

A ciência se constitui como uma forma de cultura humana e como tal, representa um elemento incontestável no processo civilizatório, sendo uma atividade intelectual que tangencia todas as áreas da existência (SÁNCHEZ MORA, 2003). Todavia, uma parcela da sociedade a percebe como alheia a outras atividades humanas que não sejam aquelas que estão no âmbito da academia, dos centros de pesquisas, enfim, do universo acadêmico produtores do conhecimento sábio.

No âmbito da cultura é possível que se perceba a ciência e sua forma de comunicar-se como uma produção diferenciada de outros setores da realidade. Segundo Sánchez Mora (2003, p. 14)

Até o século XVII, a esfera da linguagem comum abrangia, quase
totalmente, experiência e realidade; hoje, ela abrange um domínio
reduzido. Nos processos de observação, experimentação e
interpretação lógica, a ciência, em especial a física, foi
abandonando a descrição e a representação literais da realidade,
para entrar em uma maior abstração, que deu lugar a um
simbolismo de princípios. A tendência à representação intuitiva e
esquemática. A síntese, que é possível obter por meio dos
conceitos de lei e relação, demonstrou ser mais valiosa do que a
apreensão em termos de objetos e coisas.

Possivelmente essa abstração, o uso de um método e utilização de uma linguagem própria distanciada da linguagem do cotidiano tornou o acesso à ciência e à sua forma de divulgação algo inatingível e incompreensível a uma boa parcela das pessoas. No passado medieval, o privilégio de entender as ciências estava com aqueles que conheciam o latim, já que todas as descrições de fenômenos da natureza se faziam nessa língua, a mesma que era usada na liturgia católica também. Galileu (1564-1642) é considerado um dos primeiros divulgadores e popularizadores da ciência por ter se utilizado do italiano para difusão das suas observações.

A invenção da imprensa tinha tirado da ciência um pouco do seu caráter privado; o trabalho escrito podia disseminar-se rapidamente, e a ciência se tornou um assunto mais público. Galileu se propôs difundir o sistema de Copérnico, o qual já tinha sido condenado pela Igreja. O papa não ia permitir que a doutrina 
copernicana fosse aceita abertamente, mas existia outra maneira de torná-la pública: Galileu começou a escrever, em italiano, o Diálogo sobre os dois principais sistemas do mundo, em 1624. Concluiu Duas novas ciências, em 1636, quando já sofria um processo instaurado pela lgreja. (SÁNCHEZ MORA (2003, p. 15).

A transgressão galileana no século XVII permitiu a ampliação ao acesso as novas informações do universo das ciências por duas razões: o advento da imprensa e o uso de línguas nacionais. O século XVII também é tributário de uma grande invenção, a publicação de trabalhos científicos com o intuito de dar conhecimentos e informações acerca deles aos interessados, geralmente integrantes das sociedades científicas também fundadas no mesmo século. Uma das primeiras diz respeito à Royal Society na Inglaterra, instituição fundada em 28 de novembro de 1660 em Londres com a finalidade de promover o conhecimento científico.

A publicação de resultados exige um simbolismo simples e compreensível que todos os cientistas possam compartilhar. As matemáticas fornecem esse simbolismo e, portanto, a notação matemática foi estabelecida como padrão de comunicação. (...) Todavia, existe uma coisa mais importante do que um simbolismo formal; o trabalho científico, para ser compreendido, requer uma clara expressão em palavras. Isso foi enfatizado pela Royal Society desde o início. (...) Os membros da Royal Society eram exortados a exporem suas descobertas - sem amplificações, sem digressões nem estilos enfatuados; a voltarem à pureza primitiva $\mathrm{e}$ à concisão, quando os homens enunciavam tantas coisas quase com idêntico número de palavras.( J. BRONOWSKI apud SÁNCHEZ MORA, 2003, p. 17).

Portanto, a divulgação científica nasce com a característica de ser clara e objetiva com a elegância inerente à própria ciência. Todavia, as características que a divulgação científica passou a ter levaram para uma complexidade diretamente proporcional ao amadurecimento e especialização dos diversos ramos das ciências, de modo que algumas revistas acadêmicas de divulgação científica são lidas por um numero restrito de pessoas que conhecem a linguagem.

Atualmente a divulgação científica se popularizou ainda mais e não somente revistas e/ou veículos especializados o fazem. Há uma enormidade de sites, revistas populares, vídeos em repositórios que divulgam e popularizam elementos da ciência. Porém, em tempos de notícias falsas e sensacionalistas, 
muitos materiais que são divulgados devem ser filtrados com o intuito de se preservar a veracidade para que não sejam dados como verdades da ciência. Cabe ao professor a função de pesquisar e filtrar esses mananciais de informação a que os estudantes em todos os níveis estão expostos.

\section{Objetivo geral}

- Identificar a importância que diversificados meios e materiais de divulgação científica pode ter para o ensino de ciências nos anos iniciais do ensino fundamental.

\section{Objetivos específicos:}

- Investigar potencialidades e limitações do uso de materiais de divulgação científica em aulas de ciências nos anos iniciais do ensino fundamental;

- Propor a inserção de materiais e fontes alternativas de conteúdos de ciências articulados com a temática da divulgação científica para a sala de aula para contribuir com a melhoria do processo de ensino-aprendizagem do aluno.

- Investigar a percepção de professores das séries iniciais do ensino fundamental sobre a divulgação científica como estratégia para o ensino de ciências.

\section{Justificativa}

Com a popularização da ciência em função das novas tecnologias de informação e comunicação os veículos que acessam, difundem, alardeiam e até alarmam as populações se tornaram comuns nos espaços midiáticos, sobretudo nas redes sociais e em sites sensacionalistas da internet. Teorias já superadas ao longo da história da ciência voltam à tona com estrutura explicativas fraudulentas, porém lógicas, como é o caso da "Teoria da Terra Plana". Como cita Pilati (2018, p. 11-12),

O discurso do conhecimento científico é utilizado de inúmeras formas, sendo presente em nossa vida, seja como estratégia para atrair atenção em um programa de entretenimento, para persuadir a comprar um livro, ou para fornecer ferramentas profissionais. $\mathrm{O}$ 
mundo está abarrotado de informações relativas ou atribuídas á ciência.

Nesse sentido, quanto de informações equivocadas e/ou de má-fé não são veiculadas para crianças e jovens sob a falsa égide da ciência? Cabe à escola o papel de educar as novas gerações para a devida distinção do que se veicula como ciência, e a divulgação científica honesta é especialmente uma boa ferramenta para isso em tempos de informações rápidas e nem sempre verdadeiras. Assim, a relevância de trabalhos que foquem esse objeto justificam a pesquisa.

\section{Metodologia}

Fazer uma abordagem reflexiva sobre a relevância e potencialidades da utilização de materiais de Divulgação Científica para o processo de ensino e aprendizagem de ciências nos anos iniciais do Ensino Fundamental, nos remete a pensar que este trabalho de pesquisa, busca apresentar para o ambiente escolar novas perspectivas de aprendizagem que incluem propor a inserção de materiais com propósitos educacionais que contribuam positivamente para a melhoria do processo de ensino-aprendizagem de ciências em sala de aula. Nesse sentido, esta pesquisa se enquadra dentro das perspectivas teórico-metodológicas da pesquisa-ação, que para a pós-doutora em pedagogia Maria Amélia Santoro Franco é:

\footnotetext{
Uma pesquisa eminentemente pedagógica, dentro da perspectiva de ser o exercício pedagógico, configurado como uma ação que cientificiza a prática educativa, a partir de princípios éticos que visualizam a contínua formação e emancipação de todos os sujeitos da prática. (FRANCO, 2005, p.489)
}

Partindo do princípio de que este trabalho busca articular a relevância e potencialidade da divulgação científica para o ensino de ciências, com a finalidade de que esses recursos sejam trabalhados no processo de escolarização dos alunos, visando à formação plena do estudante, de modo a viabilizar a potencialização do pensamento crítico e reflexivo do mesmo, foi escolhido trabalhar com o método da pesquisa-ação porque esta é uma pesquisa que apresenta um caráter formativo emancipatório que propicia a produção de novos 
conhecimentos, associados a mudanças que são produzidas na prática educativa, mediante a interação entre o pesquisador e os sujeitos envolvidos na pesquisa.

Em relação aos procedimentos que foram utilizados para nortear 0 processo de obtenção de resultados, é importante ressaltar que "Independentemente das técnicas a serem utilizadas, há que se caminhar para uma metodologia que instaure no grupo uma dinâmica de princípios e práticas dialógicas, participativas e transformadoras" (FRANCO, 2005, p. 490-491). Assim, torna-se viável trabalhar em etapas objetivando compreender 0 mundo do pesquisado, conhecer o processo de pesquisa, a construção e ressignificação do conhecimento. Dessa maneira, a pesquisa-ação contempla uma abordagem em espiral, onde as etapas de pesquisa envolvem planejamento, ação, reflexão, pesquisa, ressignificação e replanejamento. Esse método viabiliza para este presente trabalho, uma melhor compreensão do objeto de estudo, instigando dessa forma a construção de novos olhares sobre o tema que está sendo estudado.

Nesse sentido, usar a metodologia da pesquisa-ação para este projeto, que está voltado especialmente para uma intervenção no ambiente escolar, é viável porque as características que ela apresenta são eficazes para serem trabalhadas em um ambiente coletivo como a escola, pois a pesquisa-ação é uma pesquisa que se desenvolve em meio à cooperação e envolvimento de todos os participantes do projeto de pesquisa, onde a produção de conhecimentos se dá por meio da interação e do modelo do agir comunicativo que se sustenta por meio de saberes que são intersubjetivamente partilhados, contribuindo dessa forma para a integração do processo de reflexão/pesquisa e formação. Com isso, as características teórico-metodológicas da pesquisa-ação se aplicam como uma ferramenta importante para a produção de material a ser trabalhado nas aulas de ciências, pois a partir das ações coletivas e da socialização de conhecimentos e experiências que podem ser desencadeada pelo processo de investigação dessa pesquisa, esse trabalho pode contribuir para promoção de mudanças efetivas na prática do ensino de ciências nos anos iniciais de escolarização.

Com o intuito de conhecer as discussões que são realizadas sobre a articulação de materiais de divulgação científica e as possibilidades de seu respectivo uso nas aulas de ciências nos anos iniciais de escolarização, foi 
essencial realizar uma atividade de revisão bibliográfica de alguns trabalhos já produzidos, para compreender as ideias que estão sendo elaboradas e difundidas sobre essa temática, de modo, a propiciar um melhor entendimento sobre o processo de ensino de ciências no âmbito da educação fundamental. Dessa forma, foi realizada uma breve pesquisa na Revista Brasileira de Pesquisa em Educação em Ciências e na revista ENSAIO, cujo objetivo foi selecionar trabalhos que articulavam a temática da divulgação científica com o ensino de ciências, visando entender como estes estão sendo inseridos e trabalhados no âmbito da educação escolar, e em especial nas aulas de ciências do ensino fundamental. A partir dessa discussão inicial, será apresentada no conteúdo dessa análise, uma síntese geral das principais ideias que permeiam o processo didáticometodológico que o uso de materiais de divulgação científica potencializa para auxiliar 0 processo de ensino-aprendizagem dos alunos acerca dos conhecimentos científicos.

Para o alcance dos objetivos da pesquisa, mediante uma reflexão sobre o que a bibliografia especializada aponta sobre divulgação científica e ensino de ciências, identificou-se alguns critérios a serem utilizados pelos professores para orientá-los a respeito do que esses materiais precisam apresentar para serem alvo de escolha e uso no processo de ensino e aprendizagem. Assim, com base nesses critérios, elaborou-se dois roteiros para as sequências didáticas, esses foram submetidos à análise de quatro professores que atuam nos anos iniciais do ensino fundamental em busca de sua percepções. A análise se pautou em questionamentos pré-estabelecidos que podem ser vistos no quadro 1 (Ficha de análise crítica) no capítulo 3. 


\section{CAPÍTULO 2 Uma fundamentação teórica}

\section{O QUE SE ENTENDE POR DIVULGAÇÃO CIENTÍFICA?}

É imprescindível reconhecer que não há um único significado para o termo divulgação científica. Nesse contexto, torna-se essencial conhecer algumas definições, já que diversos autores abordam o termo sob perspectivas teóricas diferentes. Para o jornalista científico Wilson da Costa Bueno, a divulgação científica consiste em "todo e qualquer processo ou recurso utilizado para a veiculação de informações científicas e tecnológicas" (BUENO,1985, p.1421). José Reis, um importante jornalista e divulgador científico brasileiro, compreende a divulgação científica como sendo:

O trabalho de comunicar ao público, em linguagem acessível, os fatos e princípios da ciência, dentro de uma filosofia que permita aproveitar os fatos jornalisticamente relevantes como motivação para explicar os princípios científicos, os métodos de ação dos cientistas e a evolução das ideias científicas (Reis apud BUENO, 1985, p.1422).

Ana Maria Sanchéz, física e divulgadora profissional de ciências compreende que "a divulgação é uma recriação do conhecimento científico, para torná-lo acessível ao público" (SANCHÉZ MORA, 2003, p.13).

A partir dessas definições, compreende-se que a divulgação científica busca como uma de suas finalidades, popularizar o conhecimento científico para que este não fique restrito somente a comunidade científica, pois a ciência é um campo de conhecimento amplo, e reflete a sua importância em dimensões culturais, sociais, políticas e éticas, constituindo-se assim, como um instrumento que transmite saberes importantes para a formação crítica e participativa das pessoas no meio social em que estão inseridas.

A divulgação científica está presente em nosso cotidiano em diferentes espaços e veículos informativos. Por apresentar um caráter formativo, a DC apresenta para a sociedade, não só conhecimentos científicos, mas também tecnológicos. Essa função educativa da divulgação científica pode ser percebida 
em diversificados meios e ferramentas que integra e populariza o conhecimento científico e tecnológico na sociedade, tais como: revistas, jornais, mídias sociais, folhetos explicativos, por exemplo, aqueles de higiene, saúde e bem estar, documentários, livros, desenhos infantis, filmes, entre outros meios que estão mais próximos e acessíveis da grande massa da população, que em grande parte não dominam a linguagem e terminologias utilizadas pela comunidade científica. Dessa forma, esses meios anteriormente mencionados, constituem-se como um auxilio para que a população leiga tenha oportunidade de compreender, refletir e expor opiniões sobre os estudos e pesquisas que são produzidas nos espaços acadêmicos formais, por cientistas e seus pares.

\section{RELEVÂNCIA E POTENCIALIDADES DO EMPREGO DE MATERIAIS DE DIVULGAÇÃO CIENTÍFICA NO ÂMBITO EDUCACIONAL}

A escola por ser um espaço que tende a promover diferentes perspectivas de aprendizagem, busca cada vez mais apresentar para os educandos inovações e o aperfeiçoamento do ensino, com práticas pedagógicas que relacionem 0 ensino as questões que estão presentes no cotidiano do aluno, de modo a zelar pelo acesso aos conteúdos a serem socializados, mas que também tenha espaço para desabrochar e expor o seu pensamento crítico e reflexivo acerca das aprendizagens. A ciência muitas vezes parece ser algo que está distante do aluno, a ideia do sensacionalismo científico, aqui entendido como um viés editorial conferido pelos meios de divulgação que inflam, exageram ou até distorcem a verdade em busca de uma atenção maior dos leitores, pode ter sua parcela de culpa em gerar esta interpretação errônea, não só nos alunos, mas também nos professores. Nesse sentido, a escola precisa mostrar seu papel transformador em contribuir para que o ensino esteja potencializando aprendizagens significativas, explorações ativas do conhecimento, aproximando os alunos do conhecimento científico, e dando aos professores suporte e subsídios para que este tenha condições de promover a integração entre prática e teoria no processo de ensinoaprendizagem.

Levando isso em consideração, torna-se essencial enfatizar que o uso de materiais de divulgação científica em sala de aula, configura-se como uma ferramenta educativa importante para promover a integração entre educação 
formal e não formal, pois potencializa o acesso a conhecimentos que nem sempre a escola pode oferecer aos seus alunos por diferentes motivos. Dessa forma, apresentar a importância que os diversificados meios e materiais de divulgação científica, pode ter para o ensino de ciências nos anos iniciais, constitui-se como um dos objetivos dessa pesquisa, pois os propósitos educacionais que estes meios e materiais possuem, podem auxiliar na formação do pensamento crítico da criança sobre o desenvolvimento do conhecimento científico e tecnológico, estimulando-as a se interessarem por temas variados de modo criativo e provocativo.

É de suma importância reconhecer que estes materiais também apresentam além de potencialidades, algumas limitações para o uso em sala de aula, e o professor precisa atentar-se para a qualidade das informações que eles apresentam, pois muitos desses materiais podem trazer em seu conteúdo informações que sejam consideradas errôneas, desatualizadas, fantasiosas e que podem contribuir para criar uma imagem distorcida ou sensacionalista da ciência. Nesse sentido, o professor como mediador no processo de ensino-aprendizagem do aluno, precisa reelaborar os materiais de divulgação científica com a finalidade de torná-lo um instrumento didático adequado para o ensino de ciências, pois têm-se defendido 0 uso destes como instrumento de articulação entre o conhecimento tratado em sala de aula e a divulgação científica (KEMPER, ZIMMERMANN \& GASTAL, 2010), pois essa articulação pode promover melhorias na forma tradicional de abordar o conhecimento que se posiciona muitas das vezes, a mercê do livro didático. E sendo a escola uma instituição social, deve está voltada para a promoção de novas perspectivas de aprendizagem, incluindo reflexões críticas sobre ciência e tecnologia que se fazem presente nas vivências dos alunos.

\section{DISCUSSÕES REALIZADAS ACERCA DO ESTUDO DA ARTICULAÇÃO ENTRE DIVULGAÇÃO CIENTÍFICA E O ENSINO DE CIÊNCIAS}

Discute-se muito (ROCHA, 2010; BAIÃO, 2010; GOMES, 2008; KEMPER, 2008; SILVA, 2008; FONTANELLA e MEGLHIORATTI, 2013) que os textos de divulgação científica, tem se tornado uma ferramenta didática importante que modifica as práticas pedagógicas tradicionais voltadas para o livro didático, 
auxiliando o processo de alfabetização científica e tecnológica de modo a oferecer um suporte para que as atividades desenvolvidas sobre ciência complementem as discussões em sala de aula, oferecendo subsídios para uma aula mais dinâmica e interativa e que relacione os conteúdos curriculares ao cotidiano dos alunos. Sendo assim, enfatiza-se que um dos papéis da escola é estimular a criatividade e possibilitar a interação do aluno com objetos da exposição científica, para que este se aproxime ao máximo da realidade da ciência que possui implicações diretas para a sociedade. Para tanto, evidencia-se a importância que a escola tem de potencializar atividades, espaços de debates e reflexões que favoreçam a oportunidade de crescimento científico, cultural e social dos alunos. Também, discute-se a relevância e a preocupação que se tem em reelaborar as fontes de ensino da ciência para que estas não gerem reducionismos dos conceitos científicos e não prejudiquem a compreensão dos alunos, principalmente se tratando do público infantil, de modo, que este possa se apropriar adequadamente dos saberes científicos.

Assim, observa-se de maneira ampla, que as discussões evidenciam a significância que possui para o ensino de ciências, o fomento de práticas pedagógicas e ambientes de aprendizagens que possibilitem explorações ativas e a interação social dos alunos, envolvendo-os na prática e não enfatizando somente a teoria proposta nos livros didáticos. Nesse sentido, os textos de Divulgação Científica (DC) tem se configurado como uma importante ferramenta didático-metodológica que oferece recursos para favorecer as aprendizagens sobre a ciência, através de uma comunicação facilmente compreendida pela criança e que também torna as aulas de ciências mais dinâmicas e interativas porque é uma forma de instigar nos alunos o desejo por temáticas científicas que possuem dimensões culturais, sociais, políticas e éticas que interferem diretamente na sociedade.

Voltando-se para uma análise mais específica sobre as atividades e metodologias que os professores utilizam para inserir materiais auxiliares ao livro didático de ciências para o uso em sala de aula, visando ampliar os horizontes para além do livro didático e da partilha do conhecimento científico acumulado e sistematizado historicamente, é observável que se opta por atividades que desabroche o interesse do aluno sobre o saber científico, com o intuito de que 
esses saberes não sejam incorporados de maneira abstrata, mas que se realize concretamente, de modo, que este possa ter significado para a vida e contexto social em que os alunos estão inseridos. Pontua-se também que "algumas estratégias metodológicas, como as aulas expositivas, a solução de exercícios e as atividades experimentais, têm sido aparentemente, privilegiadas no ensino dos saberes próprios das Ciências Naturais". (GIRALDELLI e ALMEIDA, 2008, p. 4546). Essa metodologia pedagógica é corriqueiramente empregada no processo de ensino-aprendizagem nas aulas de ciências, contudo, nem sempre esses meios utilizados são os que melhor favorecem a socialização do conhecimento e a obtenção de resultados positivos em torno das aprendizagens incorporadas. Desse modo, faz-se necessário desenvolver ou articular às aulas, outros processos e métodos de ensino que agucem o interesse dos estudantes.

\section{POSSÍVEIS IMPASSES NA UTILIZAÇÃO DE FERRAMENTAS DE DIVULGAÇÃO CIENTÍFICA EM SALA DE AULA.}

Embora se pense em diversas metodologias que podem contribuir e auxiliar o exercício e o trabalho docente, articular novos métodos de ensino ao uso do livro didático como é corriqueiramente utilizado pelos professores para ministrar suas aulas, ainda gera alguns impasses, pois muitos professores são adeptos as formas tradicionais de ensino, o considerando suficiente para dar conta de mediar o processo de ensino-aprendizagem. Contudo, percebe-se que em meio a toda essa modernidade tecnológica que se faz presente na sociedade contemporânea, onde as informações e os conhecimentos estão sendo cada vez compartilhados mais rapidamente, e a escola por ser uma instituição que preza pela socialização de saberes e uma formação crítica e reflexiva acerca dos mesmos, precisa acompanhar esse acelerado desenvolvimento objetivando assegurar uma formação plena aos estudantes. E nesse sentido, surgem alguns impasses que interferem diretamente no ensino, e mais especificamente no ensino de ciências. Pois, esses impasses podem ser originados ainda durante a formação de professores nos cursos de graduação, que em determinadas circunstâncias pode favorecer que "os estudantes e futuros professores podem estabelecer uma relação de rejeição e insegurança com essa área do conhecimento, que pode marcar a futura prática docente" (BELUSCI e BAROLLI, 
2013, p.135). Para, além disso, outros questionamentos levantados nos trabalhos fazem referência ao papel do professor no desenvolvimento de aprendizagens significativas sobre o saber científico, pois este precisa estar antenado sobre os conhecimentos que ele mobiliza para ensinar ciências ao público infantil, buscando sempre outros conhecimentos que sejam essenciais para 0 desenvolvimento de um processo eficaz de ensino. Porém, o professor pode se sentir despreparado em buscar novas fontes de conhecimento para serem trabalhados no contexto da sala de aula, porque se acostumaram em trabalhar os conteúdos curriculares usufruindo essencialmente do livro didático. Outra inquietação, diz respeito à necessidade de adequar os materiais de divulgação científica para serem utilizados nas aulas de ciências, pois alguns materiais podem contribuir para criar uma imagem distorcida do conhecimento científico, gerar reducionismos de conceitos e ou até mesmo abordar as temáticas científicas de forma equivocada ou errônea, e nesse sentido, o professor precisa alertar-se para escolher fontes seguras e confiáveis, e adequar esse material, de modo a propiciar para as crianças uma releitura do saber científico. 


\section{CAPÍTULO 3 \\ Dados da pesquisa, sua análise e resultados}

\section{CRITÉRIOS QUE PODEM SER UTILIZADOS PARA A ESCOLHA DE MATERIAIS DE DIVULGAÇÃO CIENTÍFICA PARA O ENSINO}

A partir das discussões levantadas anteriormente acerca das potencialidades que a inserção de materiais com ênfase na divulgação científica pode apresentar para o ensino de ciências, torna-se relevante elencar alguns critérios que podem ser utilizados pelos profissionais da educação para orientálos a respeito do que esses materiais precisam apresentar para serem alvos de escolha e uso no processo de ensino e aprendizagem. Dessa forma, objetivando que os materiais selecionados possam vir a se tornar materiais de apoio ao livro didático, trazendo também para além da atualização de conteúdos, uma nova forma de abordagem destes com enfoque na temática da divulgação científica, para isso é essencial que estes materiais apresentem em sua integralidade:

- Finalidade educativa;

- Potencialidade para favorecer a troca de experiências e estratégias de socialização do conhecimento;

- Temas atuais (científicos e tecnológicos);

- Linguagem acessível;

- Estimular o interesse do aluno através da aproximação com o conhecimento científico;

- Abordar conhecimentos científicos que dialoguem com a organização curricular de conteúdos a serem trabalhados nas aulas;

- Promover consciência crítica e reflexiva sobre a ciência;

- Proporcionar debates e interlocução com diversas áreas de conhecimento de modo a promover o desenvolvimento cultural; 


\section{EXEMPLIFICAÇÃO DE MÍDIAS E INSTRUMENTOS QUE VEICULAM TEMÁTICAS DE DIVULGAÇÃO CIENTÍFICA, QUE PODEM FAZER PARTE DAS ESCOLHAS DOS PROFISSIONAIS DA EDUCAÇÃO.}

A escolha dos materiais foi feita com base nos critérios acima mencionados, que foram elaborados a partir da análise de trabalhos feitos e publicados sobre a articulação de materiais de DC e o ensino de ciências. Dentre uma gama enorme de variedades, selecionamos algumas opções que se enquadram dentro dos critérios listados e também dentro das perspectivas e objetivos desse trabalho de pesquisa. Abaixo estão print screen dos sites (Fig. 1, 2 e 3), Blog (Fig. 4, 5) e canais do YouTube (Fig. 6, 7) como exemplos de ferramentas de divulgação científica que se enquadram nos critérios elencados:

\section{REVISTAS:}

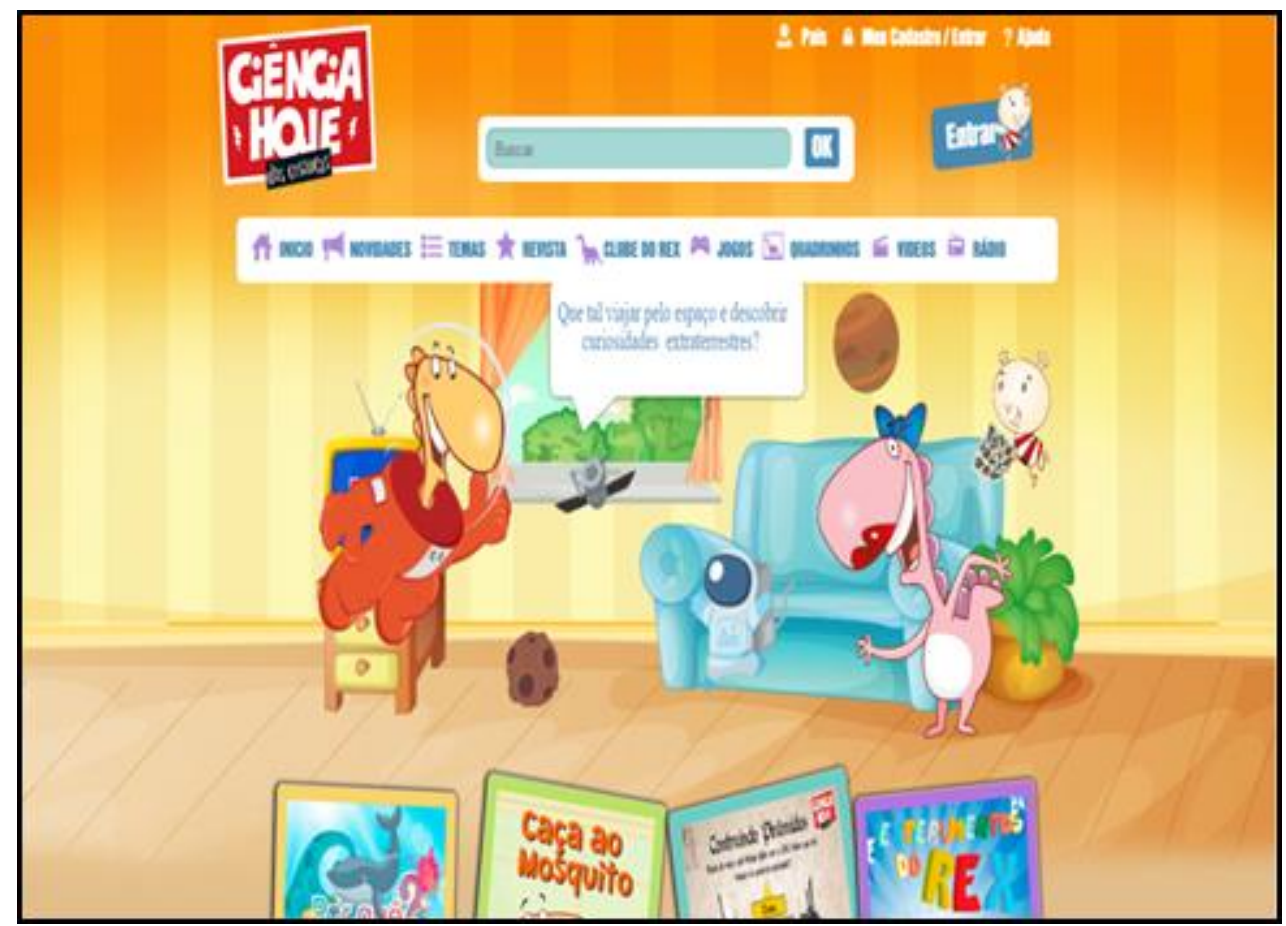

Figura 1 - Print screen do site Ciência Hoje das Crianças < http://chc.org.br/> 


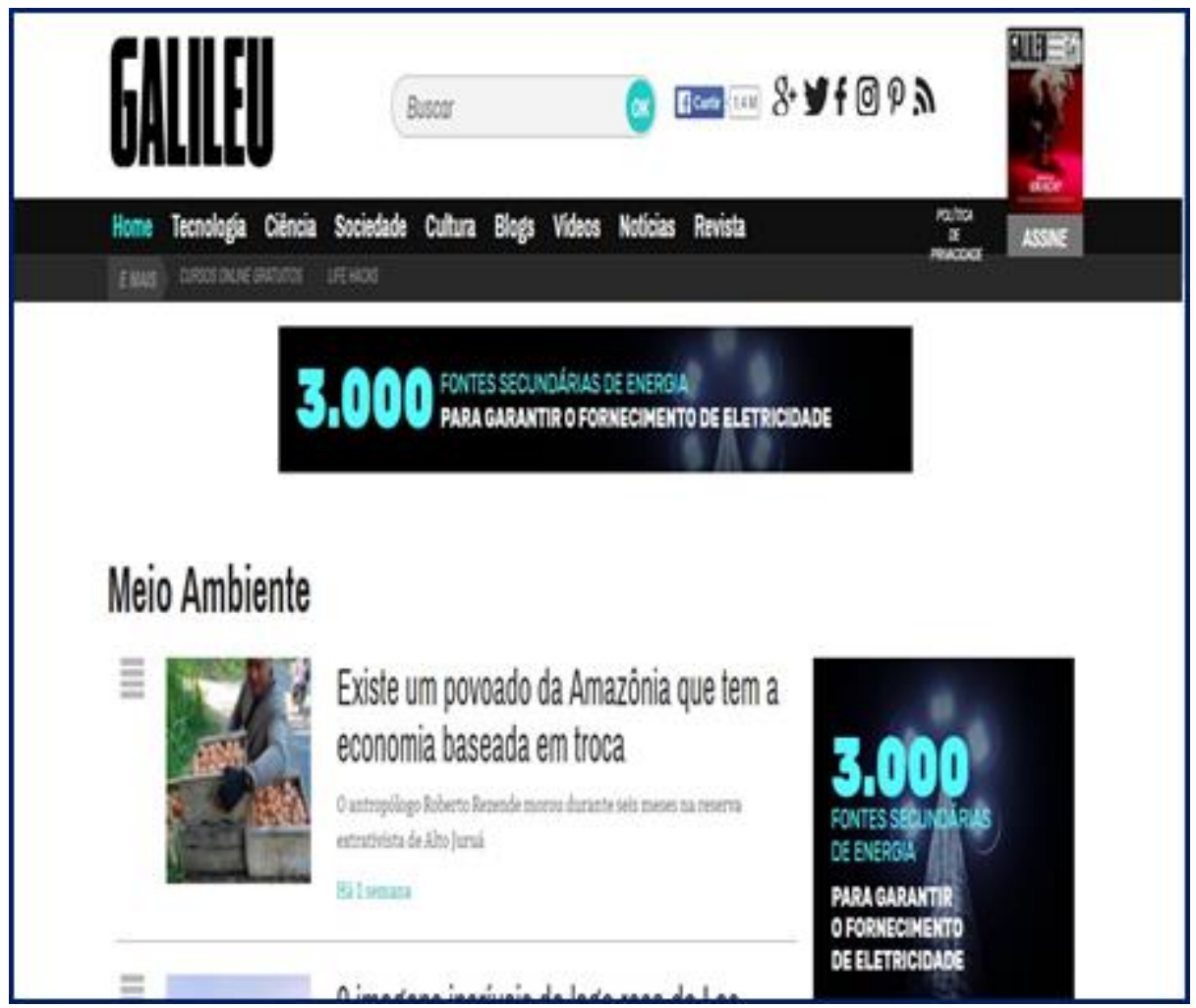

Figura 2 - Print screen do site Galileu

<http://revistagalileu.globo.com/Ciencia/Meio-Ambiente/noticia/plantao.html >

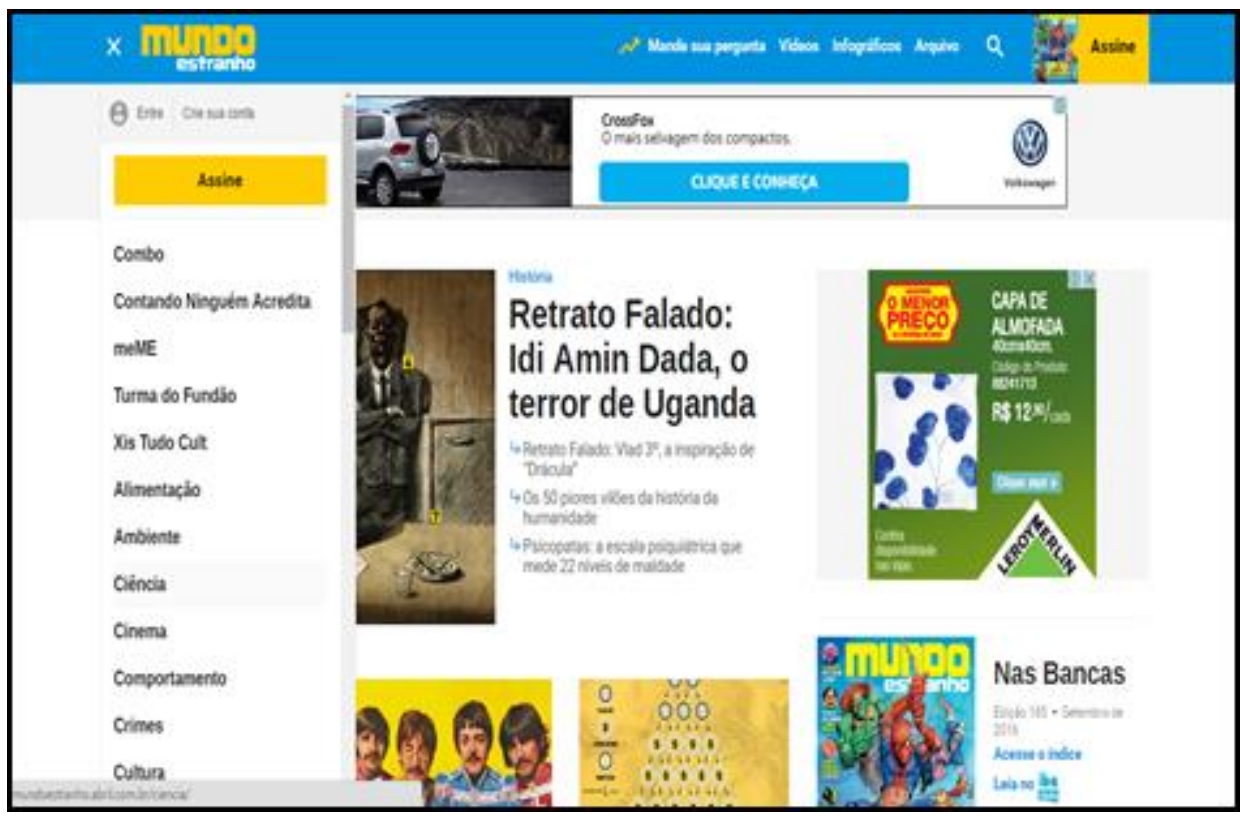

Figura 3 - Print screen do site Mundo Estranho http://mundoestranho.abril.com.br/ 
BLOGS

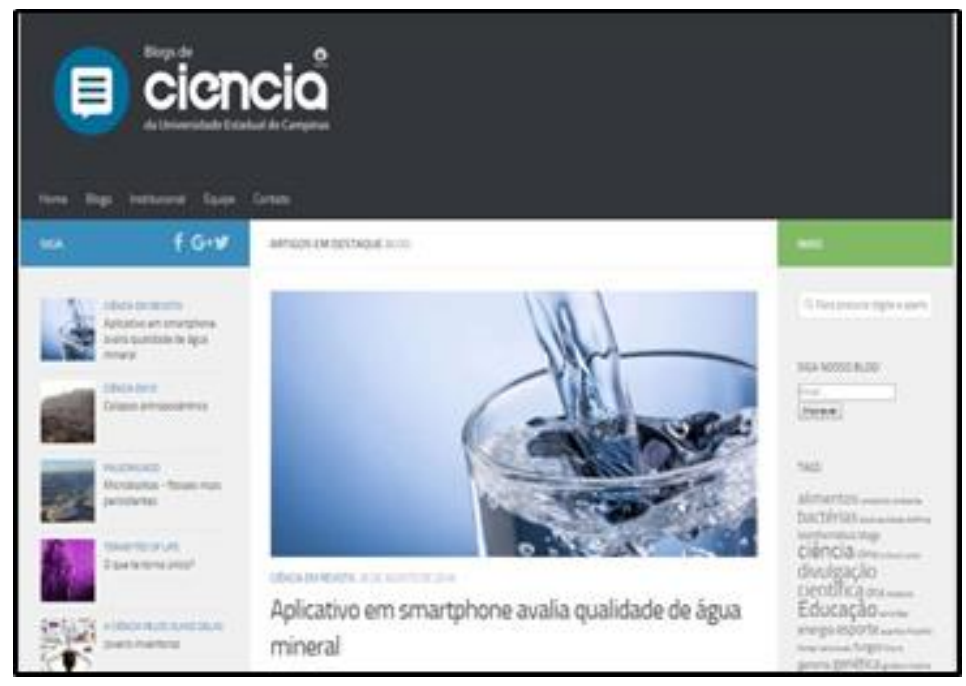

Figura 4 - Print screen do Blogs de Ciências http://www.blogs.ea2.unicamp.br/pt_BR/blog/2016/08/

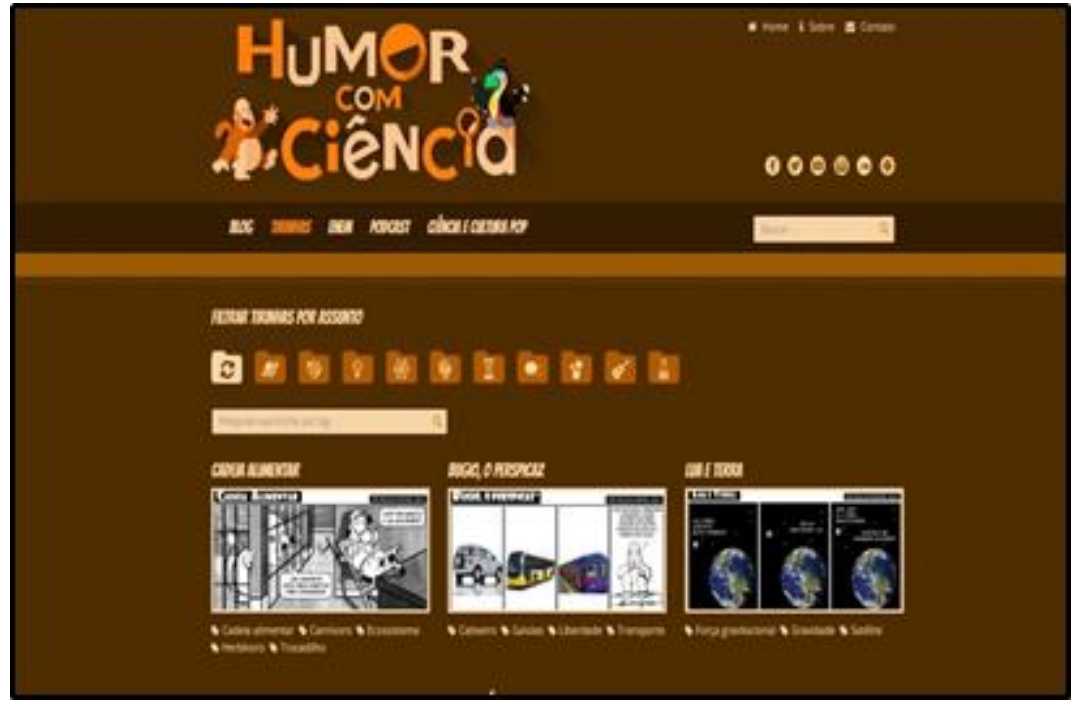

Figura 5 - Print screen do blog Humor com Ciência http://www.humorcomciencia.com/ 
CANAIS DE VÍDEOS (DISPONÍVEIS NO YOUTUBE)

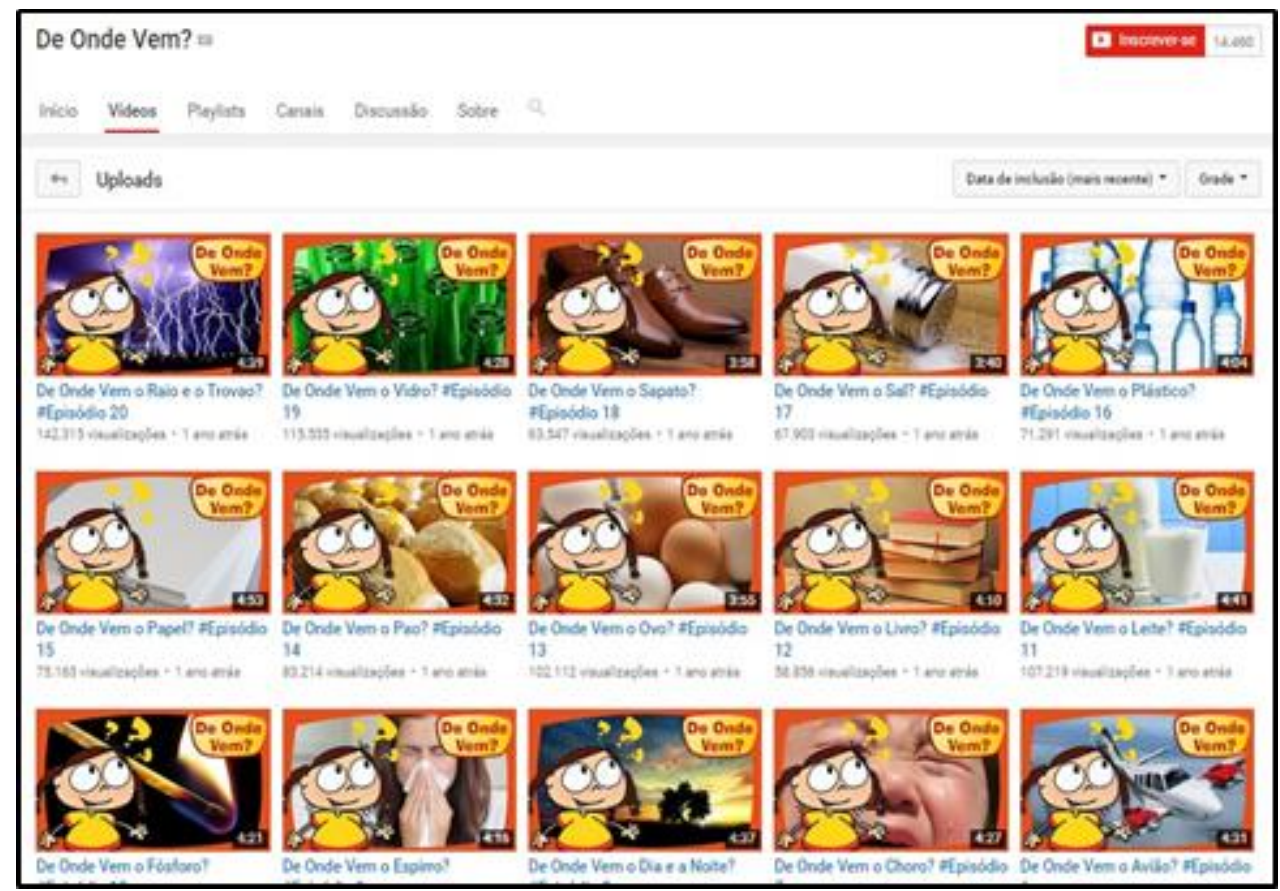

Figura 6 - Print screen do canal do Youtube "De Onde Vem?"

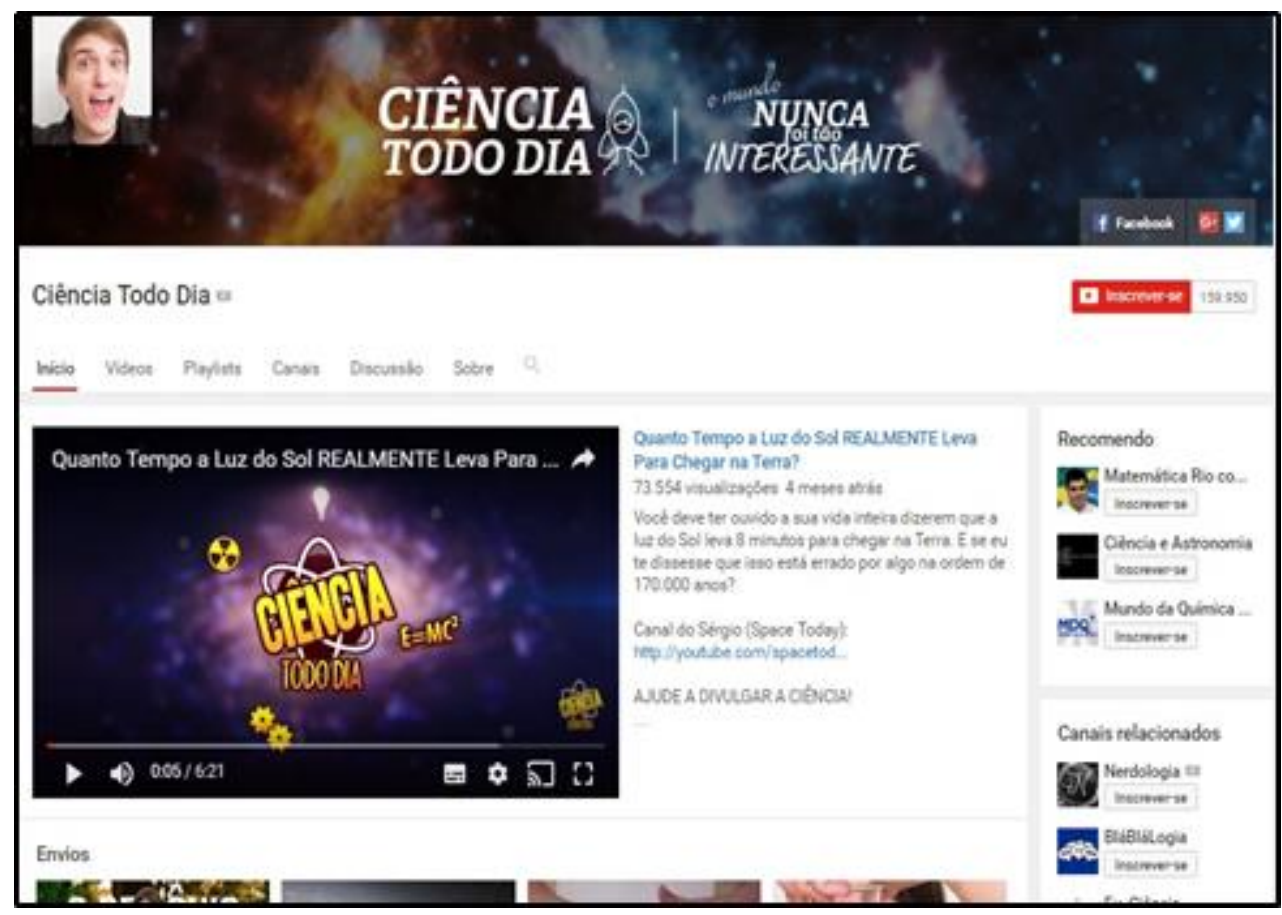

Figura 7 - Print screen do canal do Youtube "Ciência todo Dia" 


\section{Elaboração do material/roteiros de aula}

A partir da seleção desses materiais, optou-se por trabalhar com o canal de vídeo "De Onde Vem", porque ele apresenta em seu conteúdo vídeos de curta duração, feito através de animações com enfoque nos conhecimentos científicos, que apresenta uma linguagem acessível para o público infantil que facilita a compreensão e contribui para prender a atenção da criança por se tratar de vídeos interativos e dinâmicos. Escolheu-se trabalhar com dois vídeos desse canal e dessa maneira elaborou-se dois roteiros de aulas, um para cada vídeo, mostrando uma possibilidade de abordar o tema em sala de aula. Assim, buscouse produzir um modelo de roteiro de aula que contemplasse um melhor aproveitamento do tempo da aula, de modo a favorecer a socialização dos conhecimentos a serem trabalhados.

\section{Etapas de elaboração do roteiro de aula:}

1. Escolha do tema: apresenta de forma geral o tema que será abordado em sala de aula;

2. Objetivo: traz um panorama sobre o que se pretende com a abordagem do tema em sala de aula;

3. Conteúdo: apresenta os conteúdos científicos que o tema propõe para ser socializado durante a aula;

4. Metodologia: apresenta os meios/recursos que o professor pode utilizar para abordar o conteúdo;

5. $1^{\circ}$ momento da aula: consiste em instigar os alunos a falarem um pouco sobre os conhecimentos prévios que possuem sobre o tema da aula, e fazer a abordagem do conteúdo,

6. $2^{\circ}$ momento da aula: consiste em elaborar uma atividade para sintetizar o conteúdo trabalhado, que pode ser desde uma dinâmica em grupo até a criação de um jogo que envolva a turma com questionamentos e reflexões sobre o tema da aula;

7. $3^{\circ}$ momento da aula: consiste em verificar o que o aluno aprendeu na aula, através da elaboração de alguma atividade avaliativa; 
Seguindo essas etapas elaboramos os seguintes roteiros de aulas que podem ser um instrumento de socialização de conhecimentos para serem aproveitados nas aulas de ciências nos anos iniciais de escolarização:

ROTEIRO DE AULA 1

\begin{tabular}{|c|c|}
\hline & ROTEIRO DE AULAS /CIĖNCIAS \\
\hline OBJETIVO & $\begin{array}{l}\text { - Conhecer a origem do papel; } \\
\text { - Compreender o processo de produção; }\end{array}$ \\
\hline CONTEÚDO & $\begin{array}{l}\text { - História da China; } \\
\text { - Composição do papel; }\end{array}$ \\
\hline METODOLOGIA & $\begin{array}{l}\text { - Exposição oral; } \\
\text { - Exposição de vídeo; } \\
\text { - Atividade em grupos. }\end{array}$ \\
\hline
\end{tabular}




\begin{tabular}{|c|c|}
\hline $\begin{array}{c}1^{\circ} \\
\text { MOMENTO }\end{array}$ & $\begin{array}{l}\text { - Questionar os alunos sobre a origem do papel } \\
\text { A) vocês sabem de que é feito o papel? } \\
\text { B) vocês sabem como surgiu o papel? Onde se escrevia } \\
\text { antes da invenção do papel? } \\
\text { - Apresentar o vídeo da Kika- de onde vem o papel; } \\
\text { https://youtu.be/riUaQWOVG0k } \\
\text { C) o que vocês aprenderam ao assistir o vídeo? }\end{array}$ \\
\hline $\begin{array}{c}2^{\circ} \\
\text { MOMENTO }\end{array}$ & $\begin{array}{l}\text { - Trabalhar o texto da revista Mundo Estranho: Como é } \\
\text { feito o papel? } \\
\text { (disponível em: } \\
\text { http://mundoestranho.abril.com.br/tecnologia/como-e-feito-o- } \\
\text { papel/). } \\
\text { - Solicitar a leitura desse texto; } \\
\text { Fazer exposição oral do conteúdo abordando os } \\
\text { seguintes tópicos: } \\
\text { A) origem; } \\
\text { B)composição; } \\
\text { C) tipos; } \\
\text { D)produção; } \\
\text { - Questionar os alunos sobre o que eles entenderam a } \\
\text { partir da leitura e da explicação; refazer as perguntas do } \\
1^{\circ} \text { momento que introduziu o tema da aula. }\end{array}$ \\
\hline
\end{tabular}




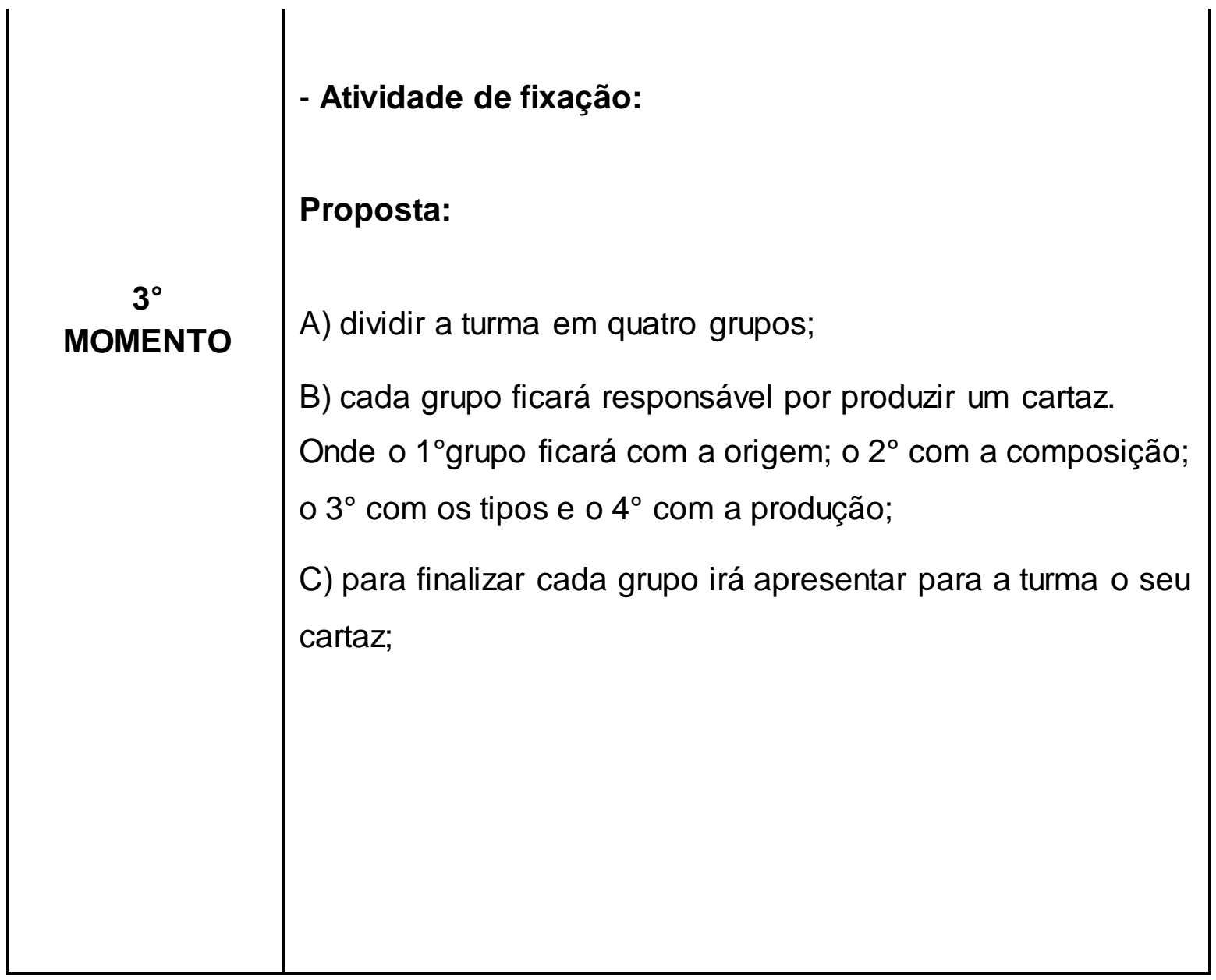

ROTEIRO DE AULA 2

ROTEIRO DE AULAS/ ciências

\begin{tabular}{|c|l|}
\hline OBJETIVOS & $\begin{array}{l}\text { - Conhecer os movimentos realizados pela Terra; } \\
\text { - Compreender a origem do dia e da noite. }\end{array}$ \\
\hline CONTEÚDO & - Movimentos de rotação e translação da Terra. \\
\hline
\end{tabular}




\begin{tabular}{|c|c|}
\hline METODOLOGIA & $\begin{array}{l}\text { - Exposição oral; } \\
\text { - Exposição de vídeo; } \\
\text { - Produção de texto para sintetizar o conteúdo; } \\
\text { - Atividade em grupos. }\end{array}$ \\
\hline $\begin{array}{c}1^{\circ} \\
\text { MOMENTO }\end{array}$ & $\begin{array}{l}\text { Para dar inicio: A aula de hoje será sobre o Planeta Terra. } \\
\text { - Fazer questionamentos aos alunos: } \\
\text { A) a Terra está parada ou ela se movimenta? } \\
\text { B) vocês sabem de onde vem o dia e a noite? } \\
\text { - Apresentar o vídeo da Kika -de onde vem o dia e noite; } \\
\text { https://youtu.be/Nux 3PVdo9U } \\
\qquad \text { Perguntar aos alunos o que eles entenderam a } \\
\text { - Fazer uma exposição oral do conteúdo } \\
\text { A) falar que a Terra realiza movimentos e que não é estática, } \\
\text { sendo assim, os principais movimentos são os de rotação e } \\
\text { de translação. } \\
\text { B) Explicar aos alunos que o movimento de rotação é } \\
\text { responsável pelos dias e noites e que consiste no giro que a } \\
\text { Terra realiza em torno de si mesma, e precisa de } 24 \text { horas } \\
\text { para ser concluído. E que o de translação é incumbido da } \\
\text { sucessão dos anos e das estações. Nesse caso a Terra gira } \\
\text { em torno do Sol de forma elíptica, variando a distância entre } \\
\text { os corpos, para a realização total desse movimento são } \\
\text { necessários } 365 \text { dias e } 6 \text { horas. } \\
\text { Disponível: } \\
\text { http://educacao.uol.com.br/disciplinas/geografia/movimentos- } \\
\text { da-terra-rotacao-translacao-e-estacoes-do-ano.htm } \\
\text { - Trabalhar com a turma a leitura do texto da revista }\end{array}$ \\
\hline
\end{tabular}




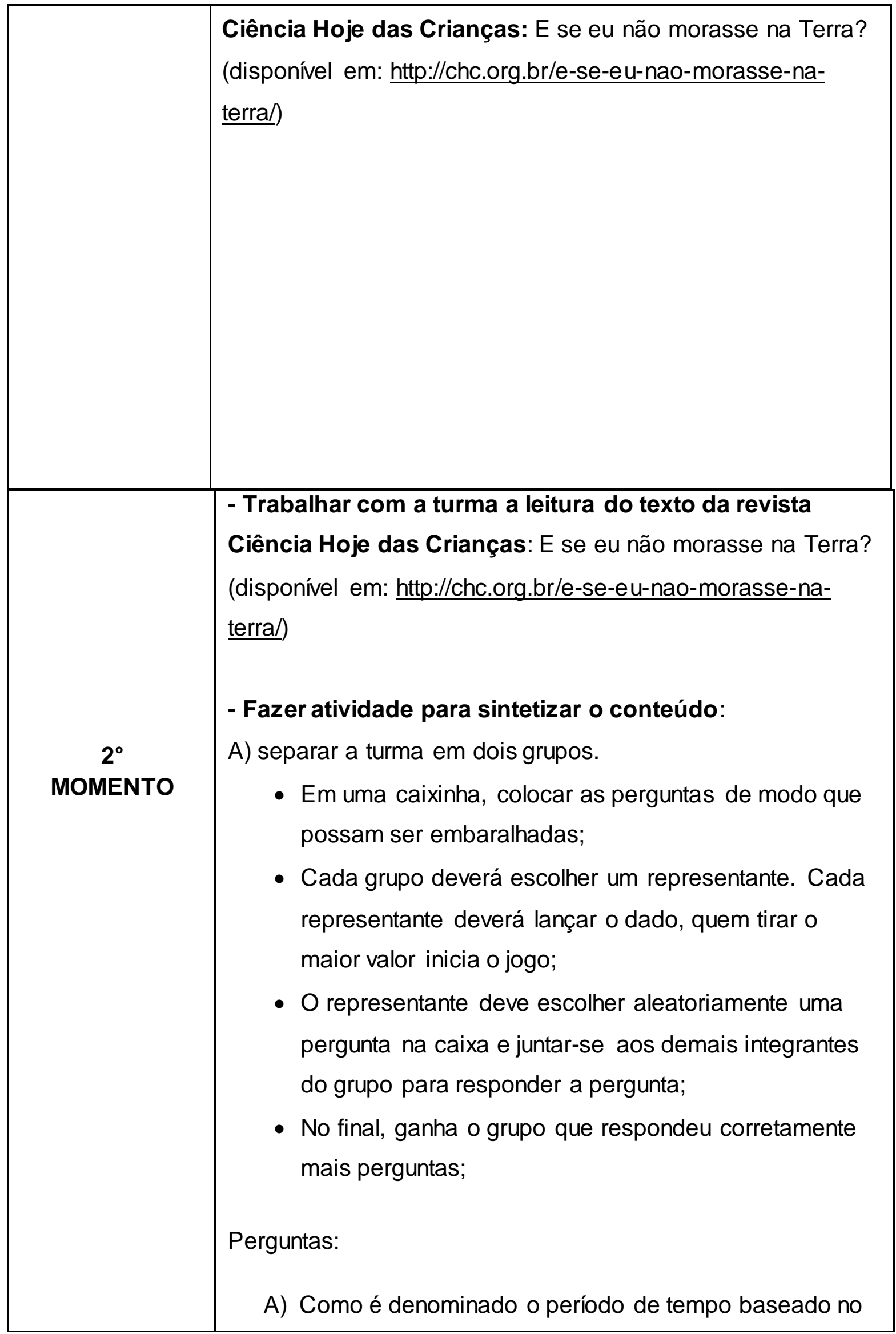




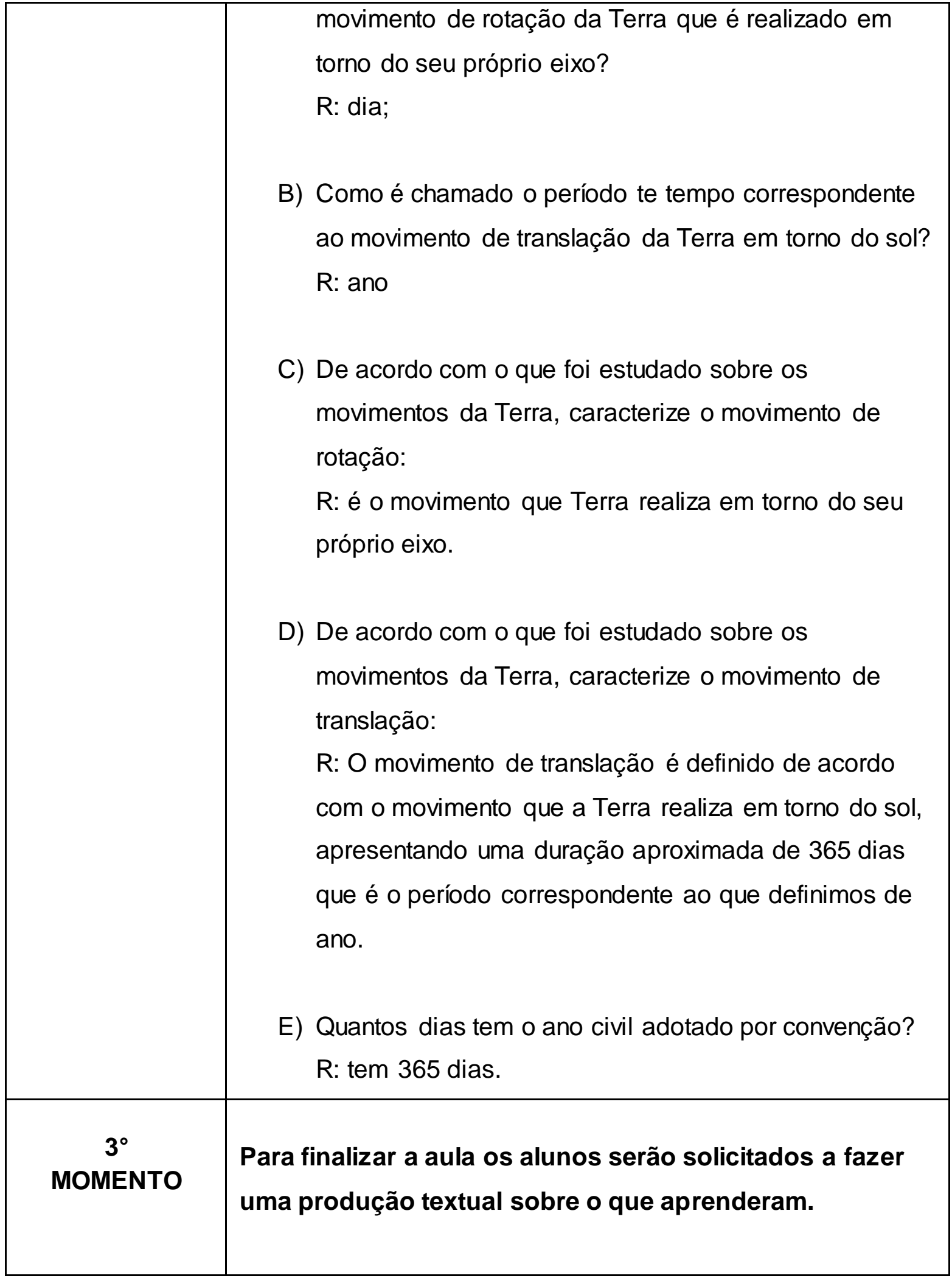

Mediante a produção desse material com finalidade educativa para ser utilizado nas aulas de ciências dos anos iniciais, espera-se que a partir deles 
outros materiais possam ser elaborados com o intuito de ser um instrumento de apoio para a melhoria do ensino de ciências que muitas vezes é abordado de forma tradicional embasado somente no uso do livro didático. Dessa maneira, temos como expectativa futura para esta proposta, a inserção de materiais e fontes alternativas de conteúdos de ciências articulados com a temática da divulgação científica para a sala de aula, objetivando a melhoria do processo de ensino-aprendizagem do aluno.

Ficha de análise crítica dos roteiros de aulas produzidos para as aulas de ciências.

Partindo da elaboração de dois roteiros de aulas que tinham como intuito promover uma aula mais interativa, abordando conhecimentos científicos importantes para serem trabalhados nas aulas de ciências dos anos iniciais de escolarização, tornou-se essencial a produção de um questionário para avaliação dos referidos roteiro de aulas, que posteriormente foram aplicados a quatro professores da educação infantil, objetivando conhecer os aspectos que os mesmos consideraram positivos e/ou negativos em relação a este material educacional de apoio, que busca, sobretudo, favorecer o processo de ensinoaprendizagem, de modo a tornar as atividades escolares mais abrangentes e dinâmicas, proporcionando reflexões e ações práticas alinhadas à temática da divulgação científica no contexto de sala de aula.

Quadro 1. Ficha de análise crítica:

\begin{tabular}{|c|c|}
\hline $\begin{array}{c}\text { Tempo de atuação nos anos } \\
\text { iniciais: }\end{array}$ & Ano em que atua no primeiro semestre de 2017: \\
\hline Pergunta & Análise crítica do professor \\
\hline
\end{tabular}




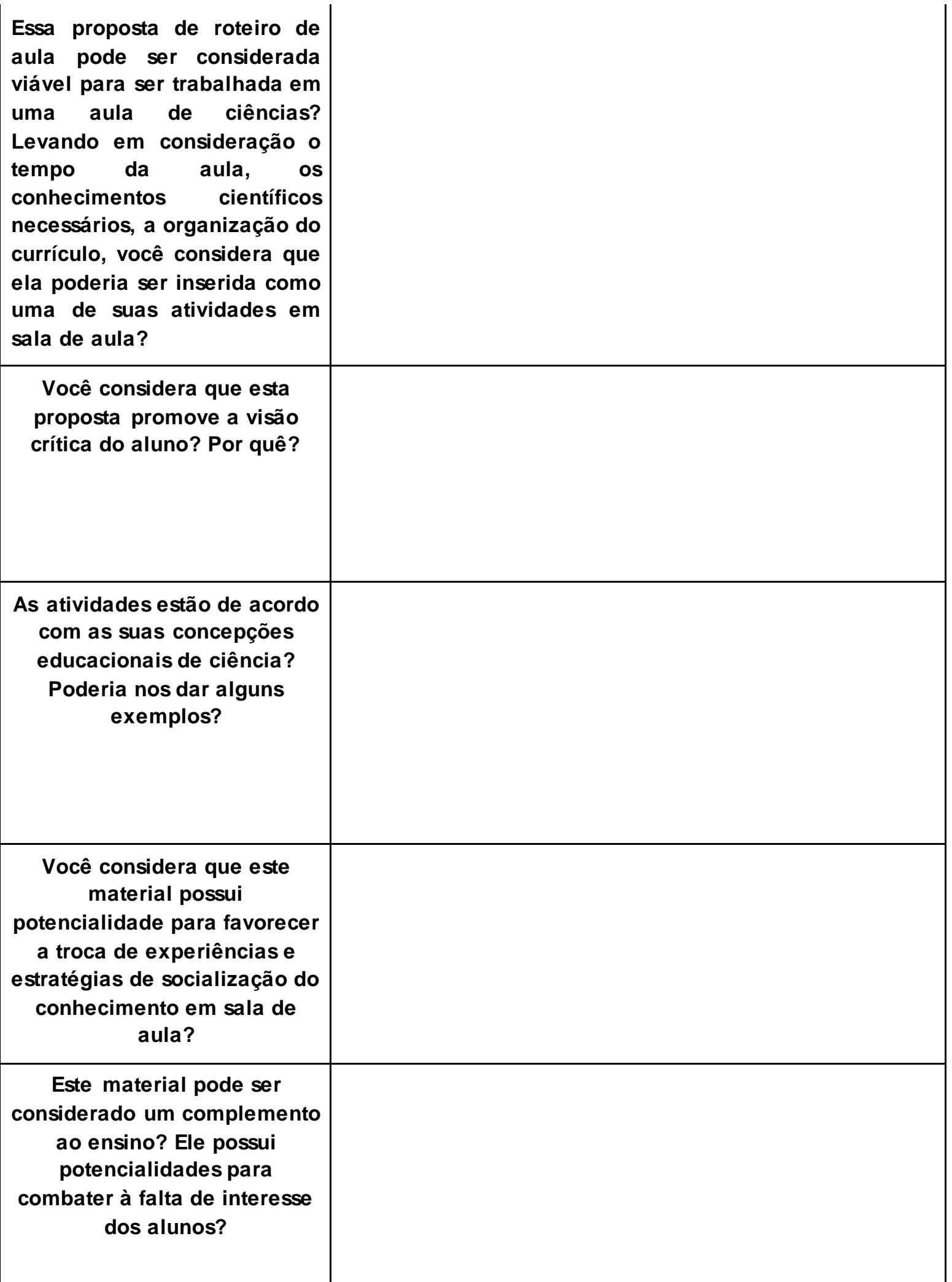




\begin{tabular}{|l|l|}
$\begin{array}{l}\text { Você considera que este } \\
\text { material contribui para a } \\
\text { criação de perspectivar no } \\
\text { aluno sobre } r\end{array}$ \\
$\begin{array}{l}\text { desenvolvimento científico e } \\
\text { tecnológico? }\end{array}$ \\
$\begin{array}{l}\text { Você considera que este } \\
\text { material pode proporcionar } \\
\text { além de debates, uma } \\
\text { interlocução com diversas } \\
\text { áreas de conhecimento de } \\
\text { modo a promover um melhor } \\
\text { processo de ensino } \\
\text { aprendizagem? }\end{array}$ \\
\hline
\end{tabular}

\section{Análise dos dados obtidos mediante as respostas dadas pelos professores}

Os professores que participaram respondendo aos questionários foram selecionados de forma voluntária. No que diz respeito ao perfil desses quatro profissionais é indispensável destacar que atualmente, todos exercem a profissão docente na rede pública de ensino, lecionando para alunos do primeiro ao quinto ano da educação infantil. Salienta-se que o tempo que eles possuem de magistério nos anos iniciais de escolarização varia entre um e cinco anos.

De modo geral, as perguntas são de cunho qualitativo e de caráter discursivo, tendo como objetivo fazer uma análise crítica dos dois roteiros de aulas elaborados na primeira etapa deste trabalho. As perguntas apresentadas nas fichas de análise foram utilizadas para ambos os roteiros de aulas, que se distinguem um do outro pela temática que abordam, assim, o roteiro de aula 1abrange a temática da produção do papel que pode ser alinhada ao contexto da sustentabilidade nas aulas de ciências e o roteiro de aula 2 faz uma abordagem do conhecimento científico acerca dos movimentos do planeta Terra,

Partindo desses esclarecimentos iniciais, passaremos a analisar mais detalhadamente as perguntas e as opiniões que os professores expressaram sobre a possibilidade de inserção desse material como instrumento educacional 
de apoio ao livro didático no contexto da sala de aula de ciências para alunos dos anos iniciais de escolarização.

A primeira pergunta almejava verificar se os professores consideraram que esses roteiros de aulas apresentavam uma proposta didática viável para ser inserida e trabalhada como atividade de aula, levando em consideração o tempo, os conhecimentos científicos e a organização do currículo. De acordo com os dados coletados nos questionários, foi possível observar que os quatro professores consideraram ambos os roteiros de aulas como sendo materiais importantes para serem inseridos e trabalhados com os alunos nas aulas de ciências. Um dos quatro professores respondentes aponta:

- Sim, mas sugiro que leve material que eles possam tocar, por exemplo, diferentes tipos de papéis. (resposta dada ao roteiro de aula 1).

- Sim, ele aborda um tema relevante. Achei essa aula excelente, mas sugiro levar algo que os alunos possam tocar (um globo, por exemplo). (resposta dada ao roteiro de aula 2 - Professor 1 ).

Observa-se mediante a opinião desse professor, que embora ambos os roteiros de aula tenham sido considerados viáveis para o contexto de sala de aula, há uma preocupação de aproximar o aluno do conhecimento científico de uma forma mais interativa, nesse caso, através da experimentação, potencializando a oportunidade dos alunos de manusearem materiais que contribuam para que o conhecimento não seja socializado de maneira abstrata, mas que este possa se fazer de maneira concreta no processo de ensino aprendizagem, pois as atividades que envolvem experimentação além de apresentarem um caráter lúdico que viabiliza um aproveitamento mais eficaz das aprendizagens, ainda contribuem para gerar motivação para o desenvolvimento das atividades. Entendendo-se dessa forma que:

No sistema educacional atual, existe a necessidade de se resgatar as atividades lúdicas, principalmente nos primeiros anos de escolaridade, pois estas representam um fator de interesse e motivação, que favorece a aprendizagem e contribui para desenvolvimento futuro da criança. (SILVA E SERRA, 2013, p.10)

A segunda pergunta tinha por objetivo inferir se esses roteiros de aula apresentavam uma proposta que potencializava a visão crítica do aluno. E foi 
perceptível mediante as respostas dadas pelos professores, que eles consideraram que essas sugestões de materiais voltadas para o ensino de ciências promove a visão crítica dos alunos por conter muitas informações, momentos que valorizam a participação, espaços para reflexões e debates. Destaca-se entre as opiniões expressas pelos professores que esse material como ferramenta de ensino favorece o desabrochar de uma visão crítica dos alunos:

- Porque promove ricos momentos de socialização. (Professor 2; resposta dada ao roteiro de aula1).

- Porque faz com que ele reflita sobre o vídeo. (Professor 4, resposta dada ao roteiro de aula 1 ).

- Por conter vários momentos que valorizam a participação dos alunos. (Professor 2; resposta dada ao roteiro de aula2).

Instigar o despertar de uma visão crítica dos alunos acerca dos conhecimentos científicos, configura-se como uma tarefa importante do professor como mediador do processo de ensino, pois estimular a capacidade do aluno de ler, interpretar e expor suas opiniões sobre temáticas que abrangem esses conhecimentos faz com que eles desenvolvam uma postura crítica frente aos saberes sistematizado pela escola com os assuntos do seu cotidiano. Dessa forma, para fomentar a visão crítica dos alunos sobre a ciência, torna-se essencial que eles compreendam que ela não está dissociada da sua realidade. Pois, este exercício é importante para a "legitimação de um tipo de ensino que reconheça a importância de pensar em atitudes e habilidades, além dos conteúdos ensinados, tendo em vista contribuir para a construção da cidadania dos estudantes" (GIRALDELLI E ALMEIDA, 2008, p.2).

A terceira pergunta proposta aos professores, tinha como intuito identificar se esses roteiros de aulas estavam de acordo com as concepções de ciências para eles, abarcando os conteúdos, os procedimentos metodológicos e também os objetivos de aprendizagem que esse material possui para favorecer o ensino. Entre os apontamentos feitos, foi possível verificar que os professores em sua totalidade, responderam que os roteiros de aulas estavam de acordo com as concepções que eles possuem sobre ciências e os critérios metodológicos a serem utilizados nas aulas, pois: 
- Está de acordo com o currículo, linguagem, duração dos vídeos e conteúdo. (Professor 3; resposta dada ao roteiro de aula1).

- Linguagem, duração dos vídeos, conteúdo informativo, experiências do dia a dia. (Professor 3; resposta dada ao roteiro de aula 2).

Também foi possível observar nessa terceira pergunta o cuidado que um dos professores teve em destacar a importância de abordar o conhecimento fora do ambiente de sala de aula, como um método de instigar nos alunos o interesse pela temática da aula, propiciando momentos de interação e reflexão, que se constituem como elementos essenciais para estruturar a mediação não só dos conhecimentos sistematizados, como também dos processos de socialização que os alunos desenvolvem no ambiente escolar.

- Para complementar, eu os levaria para caminhar e observar o céu e pensarmos juntos sobre o planeta. (Professor 4, resposta dada ao roteiro de aula 2 .

A quarta pergunta do questionário tinha por objetivo, identificar se os professores acharam que os roteiros de aulas de ciências possuíam potencialidades para favorecer a troca de experiências e estratégias de socialização do conhecimento em sala de aula. Mediante os relatos expressos nas respostas, foi possível observar que o objetivo de fomentar a troca de experiências e estratégias de socialização do conhecimento a partir do uso desse material, pode sim ser alcançado, pois o uso do mesmo no contexto da sala de aula tende a tornar isso possível.

- Sim, as atividades em grupo torna isso possível. (Professor 1; resposta dada ao roteiro de aula 2 ).

- Sim, pois há socialização e troca de ideias. (Professor 4; resposta dada ao roteiro de aula2).

- Sim, é um material de linguagem simples.(Professor 3; resposta dada ao roteiro de aula 1 ).

- Sim, por meio do jogo de perguntas. (Professor 4; resposta dada ao roteiro de aula 1 ). 
Essas opiniões expressas pelos professores mostram que partindo da compreensão de que os alunos estão em contato com diversas fontes de conhecimento, sejam elas fontes formais ou não formais de ensino que possuem ou não objetivos pedagógicos, entende-se que este conhecimento também proporciona trocas de experiências e estratégias de socialização ao serem trabalhados em sala de aula, pois durante as discussões, realização de atividades e interação dos os estudantes nas aulas, eles podem além de expressar suas ideias, compartilhá-las. Pois no processo de aprendizagem, o aluno adquire disposição para significar o mundo e confrontar suas convicções com as dos outros. Desse modo:

O processo de aprendizagem resulta de uma interação sóciocultural; é através dos "outros" e da linguagem que nós humanos estabelecemos relações com os objetos de conhecimento. Assim, a sala de aula torna-se um espaço de diversas interações, onde a linguagem e os processos de formação de conceitos são elementos fundamentais para a construção compartilhada dos conhecimentos na área de ciências. (LIMA e MAUÉS; 2006 p.168).

A quinta pergunta do questionário, almeja saber se os roteiros de aulas poderiam ser considerados um complemento ao ensino, e se os mesmos possuem potencialidades para combater a falta de interesse dos alunos. Ao analisar as respostas, foi possível identificar que todos os professores responderam sim, para esta pergunta. Como por exemplo:

- Sim, pois as atividades de socialização propostas são motivadoras.(Professor 2; resposta dada ao roteiro de aula 2).

- Acredito que sim, pois terão vários métodos e momentos de interação (Professor 4; resposta dada ao roteiro de aula1).

Sabemos que o ensino de ciências nas séries iniciais tem um papel importante no desenvolvimento das aprendizagens das crianças, desde que favoreçaa expressão dos modos de pensar, de questionar e de explicar o mundo dos alunos. E isso, está diretamente ligado ao fato de combater a falta de interesse dos estudantes, pois: 
Há que se disponibilizar um conjunto de metodologias privilegiadas para ajudar a criança a construir e organizar sua relação com o mundo material, que as auxilie na reconstrução das suas impressões do mundo real, proporcionando-lhes 0 desenvolvimento de novos observáveis sobre aquilo que ela investiga, indaga e tenta resolver. (LIMA e MAUÉS; 2006, p.171).

No que tange a sexta pergunta do questionário, esta tinha o intuito de descobrir se os roteiros de aulas são instrumentos importantes para a criação de perspectiva no aluno sobre o desenvolvimento científico e tecnológico. Em geral, todos os professores responderam sim para esta pergunta para ambos os roteiros de aulas. Destaca-se como principais argumentos para esta pergunta, as seguintes respostas:

- Sim, pois desperta a curiosidade. (Professor 4; resposta dada ao roteiro de aula 2 ).

- Sim, é bem interessante esse material com certeza irá criar muitas expectativas. (Professor 1; resposta dada ao roteiro de aula 1).

Observa-se que a utilização desses materiais pode contribuir para a criação de perspectiva sobre o desenvolvimento científico e tecnológico no aluno, pois este material está atrelado à temática da divulgação científica, tendo potencialidades para fomentar a compreensão dos alunos sobre a ciência, a tecnologia e suas consequências de forma crítica e reflexiva.

Por fim, a sétima pergunta do questionário, tinha por incumbência identificar se os roteiros de aulas tinham características para proporcionar uma interlocução com diversas áreas do conhecimento, de modo a promover um melhor processo de ensino-aprendizagem. $\mathrm{E}$ de modo geral, os quatro professores participantes da pesquisa afirmaram que ambos os roteiros de aulas, podem oferecer uma interlocução com outras áreas de conhecimento.

- Sim. O conteúdo desenvolvido pode ser trabalhado de forma interdisciplinar. (Professor 2; resposta dada ao roteiro de aula 1).

- Sim, podemos alinhar com psicomotricidade, usando o corpo para imitar os movimentos. Ou em português para verificar as palavras.(Professor 4; resposta dada ao roteiro de aula1). 
- Sim, é possível utilizar informações desse material para trabalhar outros temas.(Professor 1; resposta dada ao roteiro de aula2).

- Sim. O tema trabalhado pode ser desenvolvido em uma proposta interdisciplinar. (Professor 2; resposta dada ao roteiro de aula 2).

- Sim, por exemplo, com história e matemática.(Professor 4; resposta dada ao roteiro de aula 2 ).

A partir dessas respostas dadas pelos professores, percebe-se que a temática da Divulgação Científica não precisa necessariamente ser trabalhada somente nas aulas de ciências, mas também é uma proposta flexível para ser trabalhada de modo interdisciplinar, fazendo links com os demais conhecimentos que são mediados pelos professores no processo de ensino aprendizagem dos alunos.

\section{Considerações Finais}

Alinhar a temática da divulgação científica com os conteúdos socializados nas aulas de ciências nos anos iniciais de escolarização constitui-se como uma ferramenta didático-metodológica importante para promover aulas mais dinâmicas e interativas, potencializando uma maior participação e comunicação dos alunos no seu processo de aprendizagem. Possibilita também ao professor a utilização de materiais de apoio ao livro didático, de modo a fomentar um melhor aproveitamento da aula a partir de práticas pedagógicas e ambientes de aprendizagens que possibilitem explorações ativas e uma maior interação social.

Também é de suma importância ressaltar, que a articulação entre os materiais de DC e o ensino de ciências na escola, promove ricos momentos de reflexões e ações práticas que favorece o desabrochar de consciência crítica dos alunos acerca dos conhecimentos científicos, mostrando que este conhecimento não está dissociado da sua realidade.

A partir das discussões realizadas nesse trabalho de pesquisa, constata-se que a adequação de histórias infantis pode ser uma ferramenta didática interessante para ser utilizada no ensino de ciências nos anos iniciais de escolarização, com o intuito de potencializar a discussão de ideias, a troca de 
experiências, o trabalho em grupo, utilizando-se da realização de desenhos e redações para avaliar o processo de aprendizagem do aluno. O método de leitura coletiva também tem se configurado como um recurso essencial para o ensino de ciências, pois esta proposta desempenha um papel importante para mediar o relacionamento entre alunos e entre professor-aluno contribuindo para a construção de um ambiente prazeroso e instigante de aprendizagem. A metodologia das atividades experimentais também se configuram como uma prática importante para estimular o envolvimento e o interesse dos alunos pela investigação e que também contribui para valorizar o desenvolvimento de trabalhos em grupos, potencializando a comunicação entre as crianças. Essa metodologia também favorece que o aluno desenvolva uma maior autonomia, potencializa na criança o desabrochar de um pensamento mais consciente e crítico acerca dos saberes científicos que permeiam seu cotidiano, sendo assim, "atividades experimentais pelo seu caráter lúdico podem viabilizar a discussão de conceitos e fenômenos decorrentes das ciências naturais no cotidiano das crianças". (SILVA E SERRA,2013, p.9).

Para mediar o processo de ensino e verificar as aprendizagens advindas da socialização do conhecimento realizado em sala de aula, discute-se que entre a diversidade de metodologias avaliativas convencionais utilizadas para mensurar o nível de aprendizagem dos alunos, o professor também pode optar por usufruir de metodologias, como a solicitação de produção textual e de desenhos para que a partir desses registros escritos, seja possível o professor perceber como se deu a construção do conhecimento científico e as relações que os alunos fizeram com o seu cotidiano. Realizar trabalhos em grupo constitui-se uma ferramenta importante para que os alunos possam interagir mais nas aulas, de modo, participativo e autônomo e assim conhecer opiniões divergentes que contribuem para uma formação mais rica e um ensino mais diversificado.

Por fim, observa-se mediante os relatos dos professores sobre a análise dos materiais produzidos para as aulas de ciências, que estes podem ser inseridos no contexto de sala de aula, pois possuem potencialidades educativas que favorecem o processo de ensino-aprendizagem dos alunos. 


\section{Referências bibliográficas}

BAIÃO, L. S. A comunicação escrita da ciência no espaço escolar. 2010. 100 p. Dissertação (Mestrado em Educação) -Universidade de São Paulo, São Paulo, 2010.

BELUSCI, H. T; BAROLLI, Elisabeth. Impasses na formação inicial de professores das séries iniciais para o ensino de Ciências. Revista Brasileira de Pesquisa em Educação em Ciências Vol. 13, N॰12013.

FONTANELLA, D.; MEGLHIORATTI, F.A. A divulgação científica e o ensino de ciências: análise das pesquisas. VIII EPCC - Encontro Internacional de Produção Científica Cesumar. UNICESUMAR, Maringá, 2013.

GIRALDELLI, Carla Giulia. C.M; ALMEIDA, Maria José. P. M. Leitura coletiva de um texto de literatura infantil no ensino fundamental: algumas mediações pensando o ensino de ciências. Ensaio: Pesquisa em educação em ciências, vol. 10, №1. jun. 2008.

GOMES, M. da C. Revistas de divulgação científica: potencial para o ensino dos temas nutrição e metabolismo energético. 2008. 122 p. Dissertação (Mestrado em Química Biológica) -Universidade Federal do Rio de Janeiro, Rio de Janeiro, 2008.

KEMPER, A. A evolução biológica e as revistas de divulgação científica: potencialidades e limitações para o uso em sala de aula. 2008. 175 p. Dissertação (Mestrado em Educação) - Universidade de Brasilia, Brasilia, 2008.

KEMPER, Alessandra; ZIMMERMANN, Erika; GASTAL, Maria Luiza. Textos populares de divulgação científica como ferramenta didático pedagógica: 0 caso da evolução biológica. Revista Brasileira de Pesquisa em Educação em Ciências. Vol. $10 \mathrm{~N}^{\circ}$ 3, 2010.

LIMA, M.E. C.C; MAUÉS. Ely. Uma releitura do papel da professora das séries iniciais no desenvolvimento e aprendizagem de ciências das crianças. Ensaio: Pesquisa em educação em ciências, vol. 8 , ํo 2, dez. 2006.

LORENZETTI, L; DELIZOICOV, D. Alfabetização científica no contexto das séries iniciais. Ensaio: Pesquisa em educação em ciências, v. 03, n. 1. Jun. 2001.

PILATI, Ronaldo. Ciência e pseudociência: por que acreditamos naquilo que queremos acreditar. São Paulo: Contexto, 2018.

ROCHA, M. B. Textos de divulgação científica na sala de aula: a visão do professor de ciências. Revista Augustus, ํo 29, v. 14, p. 24-34, 2010. 
SÁNCHEZ MORA, Ana Maria. A divulgação da ciência como literatura. Rio de Janeiro: Casa da Ciência, 2003.

SANTORO, Maria Amélia. Pedagogia da pesquisa-ação. Educação e Pesquisa, São Paulo, v. 31, n. 3, p. 483-502, set./dez. 2005.

SASSERON, Lúcia Helena; Carvalho, Anna Maria. P.de. Escrita e desenho: Análise de registros elaborados por alunos do ensino fundamental em aulas de ciências. Revista Brasileira de Pesquisa em Educação em Ciências Vol. 10 NN$^{\circ}$ 2, 2010.

SILVA, G. B. da. Perspectivas de professores e estudantes em relação à utilização de textos de divulgação científica (TDC) em oficinas pedagógicas de genética. 2008. 170 p. Dissertação (Mestrado em Educação) -Universidade Federal de Santa Maria, Santa Maria, 2008.

SILVA, S. M; SERRA, H. Investigação sobre atividades experimentais de conhecimento físico nas séries iniciais. Revista Brasileira de Pesquisa em Educação em Ciências Vol. 13, № 3, 2013.

SIQUEIRA, Denise. Comunicação e ciência: estudo de representações e outros pensamentos sobre mídia. O Rio de Janeiro. UERJ, 2008. 